\title{
Review
}

\section{Back to Basics: Choosing the Appropriate Surface Disinfectant}

\author{
Angelica Artasensi (i), Sarah Mazzotta (1) and Laura Fumagalli *(i) \\ Dipartimento di Scienze Farmaceutiche, Università degli Studi di Milano, Via L. Mangiagalli 25, 20133 Milano, \\ Italy; angelica.artasensi@unimi.it (A.A.); sarah.mazzotta@unimi.it (S.M.) \\ * Correspondence: laura.fumagalli@unimi.it; Tel.: +39-0250319303
}

Citation: Artasensi, A.; Mazzotta, S.;

Fumagalli, L. Back to Basics:

Choosing the Appropriate Surface

Disinfectant. Antibiotics 2021, 10, 613.

https://doi.org/10.3390/

antibiotics 10060613

Academic Editor: Gregory Caputo

Received: 4 May 2021

Accepted: 17 May 2021

Published: 21 May 2021

Publisher's Note: MDPI stays neutral with regard to jurisdictional claims in published maps and institutional affiliations.

\begin{abstract}
From viruses to bacteria, our lives are filled with exposure to germs. In built environments, exposure to infectious microorganisms and their byproducts is clearly linked to human health. In the last year, public health emergency surrounding the COVID-19 pandemic stressed the importance of having good biosafety measures and practices. To prevent infection from spreading and to maintain the barrier, disinfection and hygiene habits are crucial, especially when the microorganism can persist and survive on surfaces. Contaminated surfaces are called fomites and on them, microorganisms can survive even for months. As a consequence, fomites serve as a second reservoir and transfer pathogens between hosts. The knowledge of microorganisms, type of surface, and antimicrobial agent is fundamental to develop the best approach to sanitize fomites and to obtain good disinfection levels. Hence, this review has the purpose to briefly describe the organisms, the kind of risk associated with them, and the main classes of antimicrobials for surfaces, to help choose the right approach to prevent exposure to pathogens.
\end{abstract}

Keywords: antimicrobial; disinfectant; surface disinfection; fomite; surface contamination; microorganisms

\section{Introduction}

In built environment, especially considering an indoor lifestyle, touching objects or surfaces which surround us is integral to everyday life. Such objects or surfaces if contaminated are called fomites and, in the 21st century, their role in disease transfer is higher than ever in human history. Indeed, most microorganisms found in the indoor environment are inactive, dormant, or dead and either show no impact on human health or are even beneficial. Nevertheless, fomites can become contaminated by pathogenic organisms which have a variety of negative health consequences. In fact, microorganisms can survive even for many months and multiply on surfaces or objects [1], leading to the development of secondary reservoirs. As a consequence fomites can serve as a mechanism for transfer between hosts, just think to doorknobs, elevator buttons, handrails, phones, keyboards, writing implement, etc., that are touched by a person that afterward will handle other objects (Figure 1).

Furthermore, experimental data show that touching a fomite carries approximately the same risk for the acquisition of a lot of microorganisms (i.e., Methicillin-Resistant Staphylococcus aureus-MRSA, Vancomycin-Resistant Enterococcus-VRE, and Clostridium difficile) on hands as touching an infected patient [2-5]. Consequently, preventing transmission of pathogens with disinfection procedures must be carried out not only in the high-risk sectors, like laboratories, operating rooms, intensive care units, or food-handling settings but also for hygienic behavior in everyday life on floors and on all the surfaces that frequently are touched with hands.

Therefore, environmental disinfection, hygiene habits, and the consequent maintenance of barriers are crucial in preventing infection from spreading. To develop effective policies and regulations to minimize the risk of transmission is strictly necessary to evaluate which organisms are present on the fomites. Furthermore, the choice of the effective 
antimicrobial agent is also based on the risk assessment of the microorganisms and the type of fomites

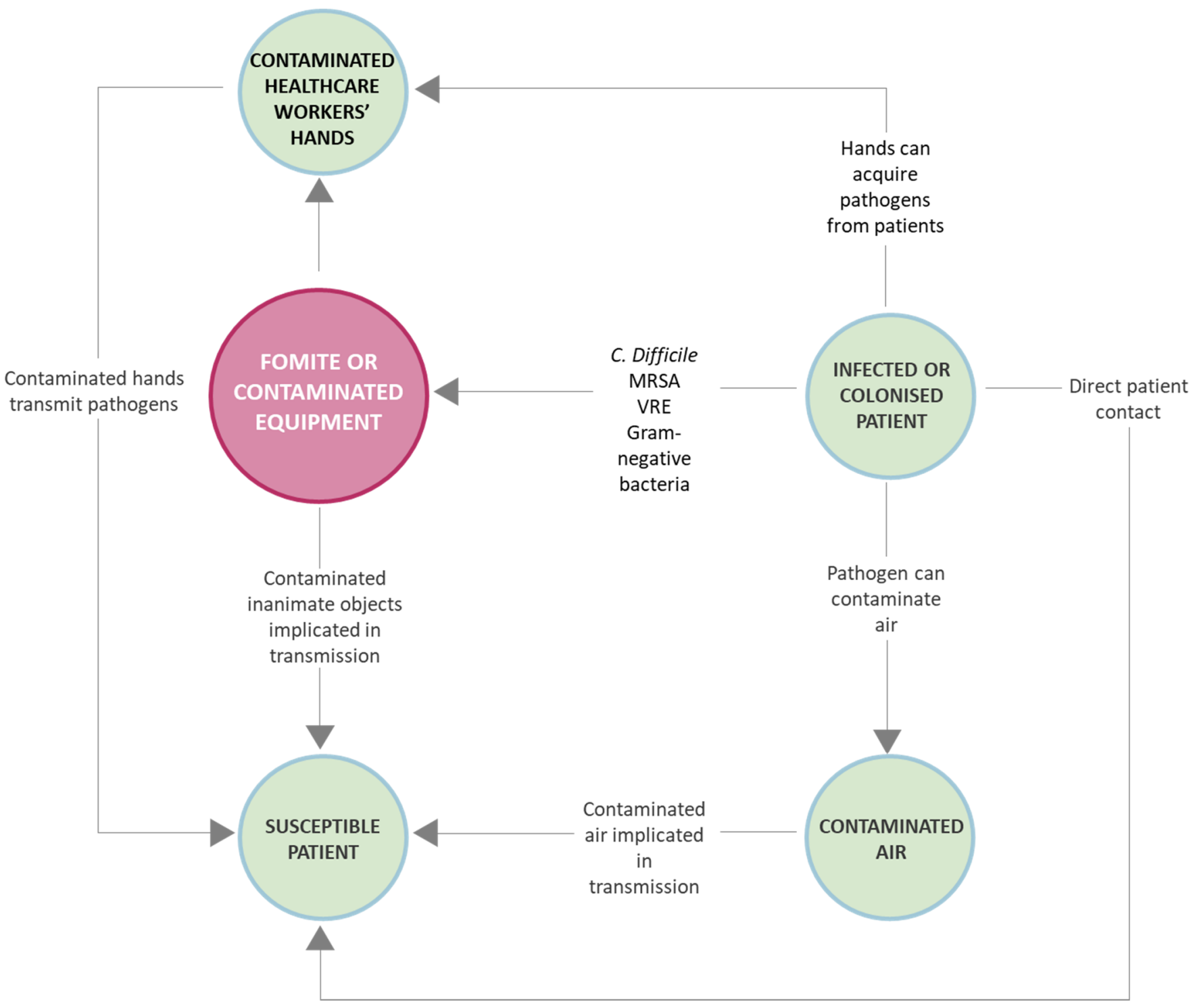

Figure 1. Generic transmission route.

Public health emergency surrounding the COVID-19 pandemic, stressed the importance of having good biosafety measures and practices, as never before. On these bases, this review has the purpose to briefly describe the organisms, the kind of risk associated with them, and the major characteristic of the main classes of antimicrobials for surfaces to help in choosing the right approach to prevent exposure to pathogens.

\section{Most Common Microorganisms on Fomites and Associated Risks}

The primary goal of disinfecting procedures is the inactivation of organisms on fomites. Generally, microorganisms belong to a diverse group such as bacteria, viral, and protozoan species [6]. These biological agents are widely found in the natural environment and, as a result, they can be found either in many work sectors or household contexts. The majority of these microorganisms are harmless; however, some of them or their metabolites may cause diseases. For example, the transmission of norovirus that causes nonbacterial gastroenteritis outbreaks is fomite-mediated as well as coccidioidomycosis. Furthermore, some of the greatest concerns regarding antibiotic-resistant bacteria transmission occur 
via fomite as reported by Julian et al. [7] for Staphylococcus pseudintermedius. Therefore, the knowledge of these organisms and their survival is fundamental to choose the right antimicrobial agents and implementing effective tactics.

\subsection{Bacteria}

Bacteria are single-celled organisms $(0.3-1.5 \mu \mathrm{m})$ with independent life and replication cycle. Bacterial cells are generally surrounded by two concentric protective layers: an inner cell membrane and an outer cell wall [8]. The cytoplasmatic membrane shares a similar structure to the eukaryote's one, but there are no sterols. Here, proteins involved in the energy production can be found like some respiratory chain protein as well as photosynthetic protein in photosynthetic bacteria that lack chloroplast. Among the proteins that constitute the cell wall, the main one is peptidoglycan (PGN), also known as murein, which provides rigidity to the structure and counteracts the osmotic pressure of the cytoplasm. PGN is characterized by a glucidic backbone of alternating units of two azotated carbohydrates, namely $\mathrm{N}$-acetylglucosamine (GlcNAc) and $\mathrm{N}$-acetylmuramic acid (MurNAc). Each MurNAc is cross-linked to a short amino acid chain, which can vary with different bacterial species [9]. The differences in structural characterization of peptidoglycan define two morphological categories: Gram-positive and Gram-negative bacteria (Figure 2).

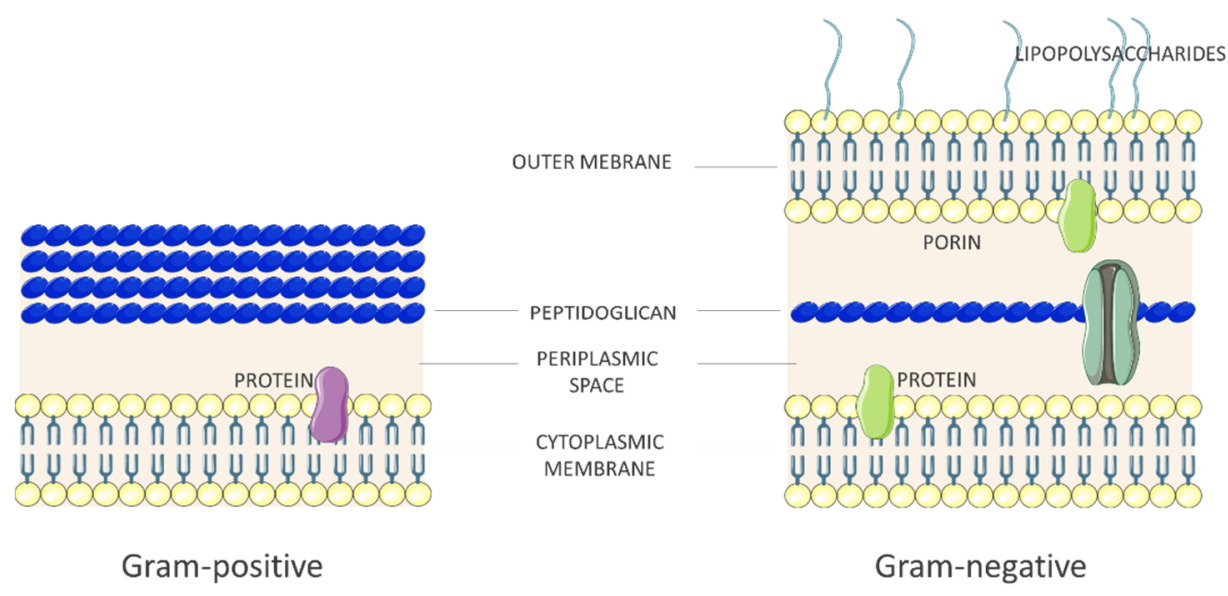

Figure 2. Gram-negative versus Gram-positive cell walls.

In Gram-positive bacteria, peptidoglycans make up about $20 \%$ of the cell wall dry weight; while in Gram-negative bacteria the thicker peptidoglycan layer contains about $10 \%$ of the cell wall dry weight [10]. Furthermore, Gram-positive cell wall has a significant amount (up to $50 \%$ ) of teichoic and teichuronic acid, which are involved in pathogenesis and play key roles in antibiotic resistance [11].

Certain bacteria may even have a third outermost protective layer called a capsule. Whip-like extensions often cover the surfaces of bacteria-long ones called flagella and short ones called pili-to become motile and seek out nutrients [12]. An alternative resource exploited by some bacteria is the formation of endospores that are dormant and highly resistant cells able to preserve the genetic material. This ruse helps the bacteria to survive even without nutrients or under extreme stress [13].

Among endospore-producing bacteria, the most common are the Bacillus and Clostridium genera [14]. Table 1 reports several endospore-forming bacteria and their relative clinical manifestations. 
Table 1. Common endospore-producing bacteria and their clinical manifestations.

\begin{tabular}{cc}
\hline Bacterial Species & Clinical Manifestation \\
\hline B. anthracis & anthrax \\
B. cereus & foodborne illness \\
B. subtilis & not pathogen \\
C. botulinum & botulism \\
C. perfringens & gas gangrene \\
C. tetani & tetanus \\
\hline
\end{tabular}

Another bacteria's survival mechanism is the formation of biofilm: clusters of bacteria that are attached to a surface and/or to each other. During biofilm development, bacteria secrete extracellular polymeric substances (EPS) which are crucial to the production of an extracellular matrix [15]. This network maintains cohesion between cells and the surface and protects the accumulation of microorganisms against chemical, biological, and mechanical stressors. In this complex arrangement of cells, there are interstitial void spaces in which water flows so nutrients and oxygen diffuse [16]. As biofilm protects from harsh conditions and resistance towards antibiotics, it represents a serious global health concern. Furthermore, biofilm is involved in persistent chronic infections $[17,18]$ and may potentially contribute to their pathogenesis [19]. In addition, some bacteria can produce a polysaccharide exocellular slime (the glycocalyx), which adheres to compromised tissue or the surfaces of biomaterials [20]. In fact, the glycocalyx is a fundamental factor in the persistence of infection linked to the prosthetic device.

\subsection{Virus}

Viruses are subcellular organisms with submicroscopic dimensions $(\mathrm{nm})$. Their core has either DNA (deoxyribonucleic acid) or RNA (ribonucleic acid) as genetic material. The core is covered by a protein coat [21], called the capsid, whose role is to protect it from degradation. Furthermore, the protein coat allows the virus to attach to a specific receptor of the host cell. In fact, viruses are obligate intracellular parasites [22], so they need host ribosomes to synthesize viral proteins. Capsid proteins are codified by the viral genome, whose short length entails a limited number of proteins with a specific function. This leads to a capsid constituted by repetitive units of one or a few proteins combined in a continuous structure [23], which can have a helicoidal or geometric symmetry. The former is characterized by a helicoidal distribution around the nucleic acid while the latter by a polyhedral or a spherical shape. Besides these styles, a few viruses have a complex architecture like poxviruses, geminiviruses, and many bacteriophages [24] (Figure 3).

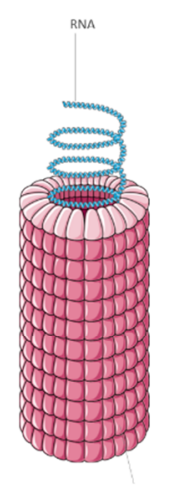

HELICAL

Tobacco Mosaic Virus

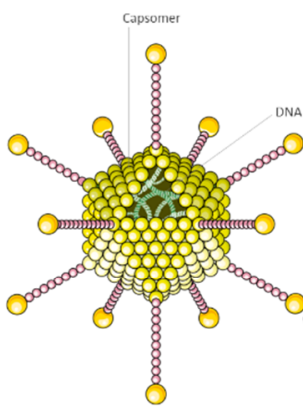

POLYHEDRAL

Adenovirus

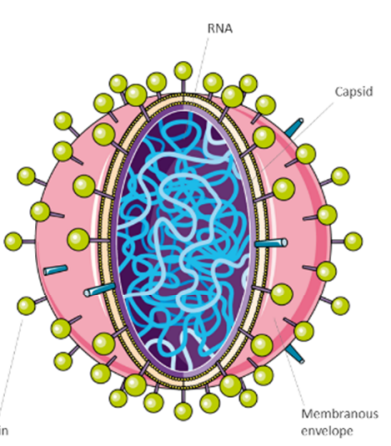

SPHERICAL

Influenza Virus

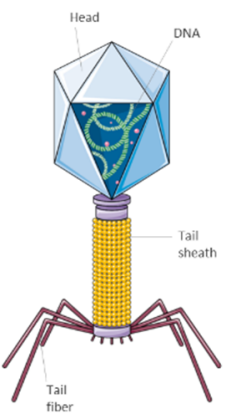

COMPLEX

Bacteriophage

Figure 3. Types of viruses architecture. 
Furthermore, some viruses show a further shell, called envelope, constituted by viral proteins and lipids. The envelope shields the virus from the immune system's detection and, in addition, facilitates the fusion with the host cell membrane [23].

\subsection{Fungi}

Fungi are a large group of eukaryotic organisms, mono or pluricellular, that also include yeast and molds. As these organisms have a rigid cell wall (rich in chitin and other polysaccharides, especially glucans as depicted in Figure 4) [25], they feed themselves secreting digestive enzymes and by absorbing organic matter from the environment: thus, they are called heterotrophic organisms. Some fungi can live by decomposing dead organic matter (saprobic) while others are a parasite of organisms, even fungi, or have developed complex symbionts as in lichens and mycorrhizae [26].

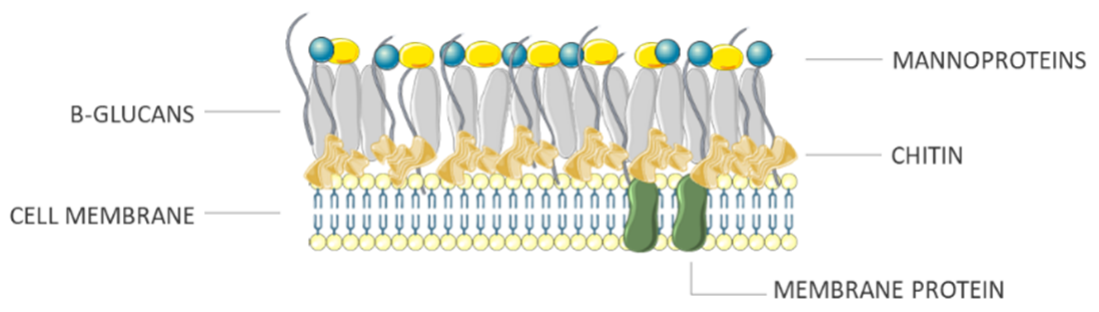

Figure 4. Fungal wall.

\subsection{Microbiological Risk Assessment}

According to the Code of Practice to the Safety, Health and Welfare at Work (Biological Agents) Regulation 2020 [27] the biological agents can be classified into four risk groups, reported in Table 2. The classification takes into account:

- Virulence-Ability of the microorganism to penetrate and multiplicate inside the host organism;

- Pathogenicity-Severity of the disease that may result;

- Transmissibility-Capability of the microorganism to be transmitted from one organism to another;

- Treatment-Availability, if any, of effective prophylaxis or therapy.

Disinfection policies should be also based on risk assessment to control crosscontamination while reducing the risk caused by exposure to infectious agents. The evaluation of the surface's risks and type together with the nature of the pathogen agent(s) should lead to the use of an appropriate and effective antimicrobial agent. Such approaches must be learned by everyone since their implementation in the routine measure improves both cleaning performance and infection prevention [28].

However, as far as possible, the number of antimicrobials to be used should be limited not only for healthy and economic reasons but also to reduce environmental pollution. Not least, the discharge of waste biocides into the environment may promote the development of both biocide and antibiotic resistance [29]. 
Table 2. Classification of biological agents.

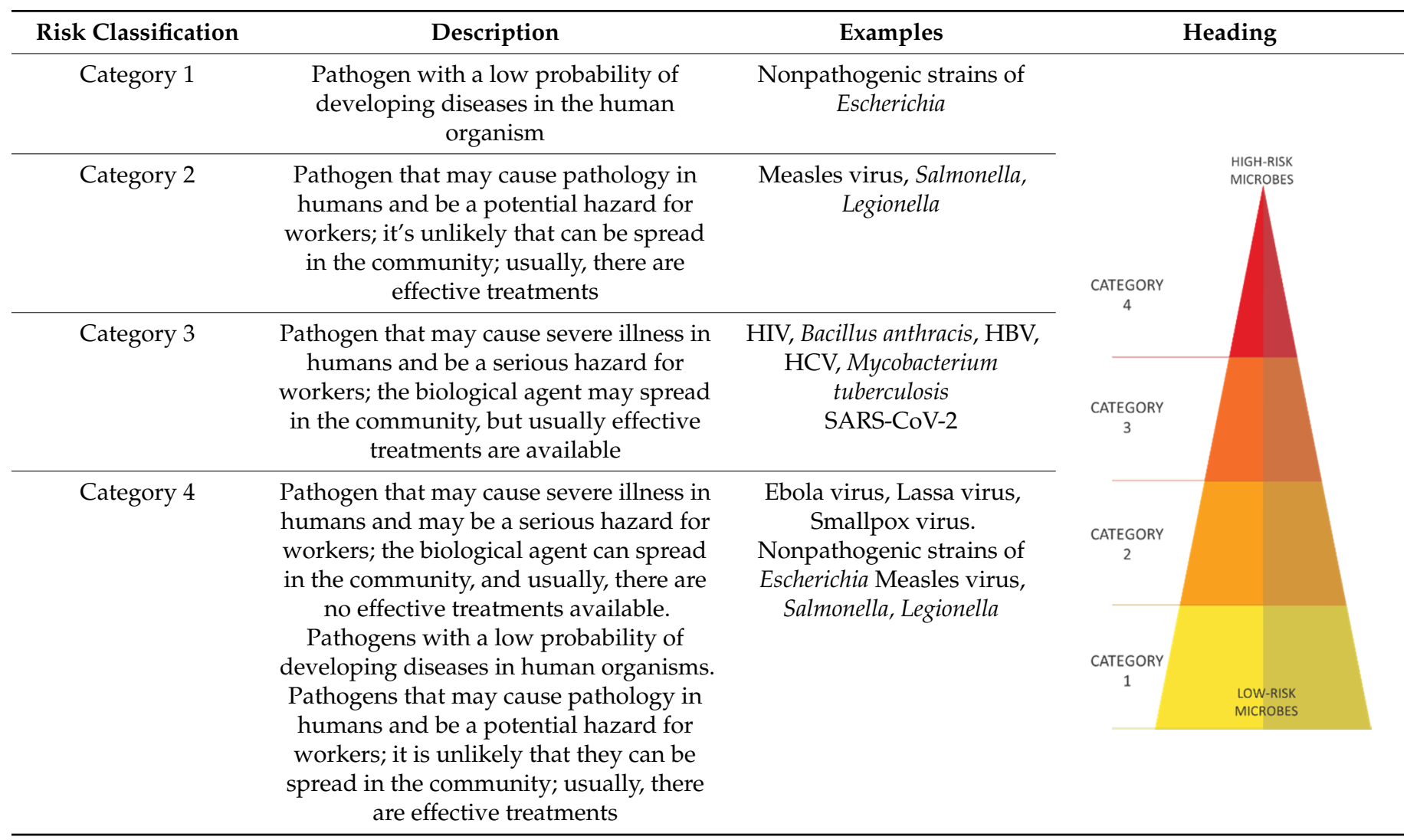

\section{Factors That Affect the Activity of Antimicrobials}

The activity of the antimicrobial agents depends on several factors, some of which are intrinsic qualities of the organism, others derived from the chemicals and external physical environment. More specifically need to be listed:

- Number and type of microorganism No disinfectant can effectively act on all microorganism classes. So proper choice of chemical germicides is fundamental. Furthermore, some microbes can persist on surfaces showing resistance to these products: for example, the production of endospores or biofilm matrix protects the pathogens from environmental influences [13,30].

- Type and concentration of the antimicrobial After choosing the proper disinfectant, the concentration of the active ingredient is a key factor: the influence of changing in the concentration of the active(s) can be measured experimentally, with the determination of the kinetics of inactivation. Moreover, the knowledge of the effect of dilution or concentration on the activity of a sanitizing agent provides some valuable information that could lead to a reduction in the exposure time. Furthermore, microbicidal concentration is also a central concept in the microbial resistance field and it is especially important nowadays with increasing knowledge and restrictions on the environmental discharges of potentially harmful chemicals [31].

- $\quad \mathrm{pH}$ of the solution The $\mathrm{pH}$ of the solution can affect the efficacy of the disinfection in two ways: a change in the agent itself and a change in the interactions between the microbicide and the microbial cell. For example, several microbicides are effective in their unionized form (Table 3). Thus, the $\mathrm{pH}$ level would affect their degree of dissociation and would decrease their overall activity. In contrast, other molecules are more effective in their ionized form. Besides these considerations, it should also be kept in mind that any alteration of the $\mathrm{pH}$ level could affect the compound's stability. As a matter of fact, disinfectant products in the sanitary field are formulated to guarantee, at a certain level of $\mathrm{pH}$, maximum germicidal efficacy. 
Table 3. Effects of $\mathrm{pH}$ level on antimicrobial activity.

\begin{tabular}{|c|c|c|}
\hline $\begin{array}{c}\text { Activity as } \\
\text { Environmental pH Increases }\end{array}$ & Classes of Disinfectants & Mechanisms \\
\hline \multirow{3}{*}{ Decreased activity } & Phenols and organic acids & $\begin{array}{l}\text { Increase in the degree of dissociation of the } \\
\text { molecules }\end{array}$ \\
\hline & Hypochlorites & $\begin{array}{l}\text { Undissociated hypochlorous acid is the most } \\
\text { fast-acting species }\end{array}$ \\
\hline & Iodine & $\begin{array}{l}\text { At low } \mathrm{pH} \text {, iodine, the most powerful } \\
\text { antimicrobial species, is the dominating one }\end{array}$ \\
\hline Increased activity & $\begin{array}{l}\text { Quaternary ammonium compounds } \\
\text { (QACs) }\end{array}$ & $\begin{array}{l}\text { Increase in the degree of ionization of } \\
\text { bacterial surface groups leading to an } \\
\text { increase in binding }\end{array}$ \\
\hline
\end{tabular}

- Formulation The formulation of a disinfectant deeply affects its activity. Several excipients, such as solvents, surfactants, thickeners, chelating agents, colors, and fragrances, can be found in these products; they can interact with the microorganisms or with the active itself and ultimately affect the activity of the formulated product. Most of the information on the effect of different excipients on the activity of disinfectants are not available, since they are often trade secrets.

- Length of exposure The microbicidal activity of chemicals usually increases with the rise of contact time. However, there is not a direct correlation between contact time and microbicidal activity, maybe due to other factors. Contact times for disinfectants are specific for each material and manufacturer. Therefore, all recommendations for use of disinfectants should follow manufacturers' specifications that must be reported on the label.

- Temperature Temperature can be an important parameter that influences the pathogen's survival. High temperature can impact vital proteins and enzymes, as well as the genome. Moreover, high temperature can boost and speed up the germicidal activity of many chemicals resulting in reduced time and improved efficacy. As a drawback, high temperature can accelerate the evaporation of the chemicals and also degrade them. Particular care is needed in using and in stocking such chemicals in tropical regions, where their shelf-life may be reduced because of high room temperature;

- Type of surfaces and precleaning process The location of microorganisms must be considered as well: to sanitize an instrument with multiple pieces or joints and channels is more difficult than a flat surface. Only surfaces that directly contact the germicide will be sanitized. Indeed, the presence of dirt is the principal reason for disinfection failure, since it could interact with the microbicide, reducing its availability or interact with the microorganisms, giving protection. Moreover, material characteristics of the surface may influence the survival of microorganisms as well: for example, porous surfaces are more difficult to clean and, consequently, to disinfect. Pretreatment of surfaces, especially when visibly soiled, is fundamental to ensure or improve the microbicidal efficacy of the disinfection procedure.

Besides the activity that is influenced by the factors listed upon, ideally, an antimicrobial agent should: (1) have a wide spectrum against microorganisms; (2) be rapid in its action; (3) be compatible with many materials; (4) be safe for humans and the environment.

\section{Most Common Antimicrobial Classes}

At present, there are numerous substances to be used on surfaces that are claimed as antimicrobial agents and they are formulated alone or in combination. The most common disinfectants can be roughly divided as halogens, alcohols, quaternary ammonium compounds (QACs), peroxigens, ozone, and UV. Generally, these antimicrobials damage a specific part of the microorganism as reported in Figure 5. 


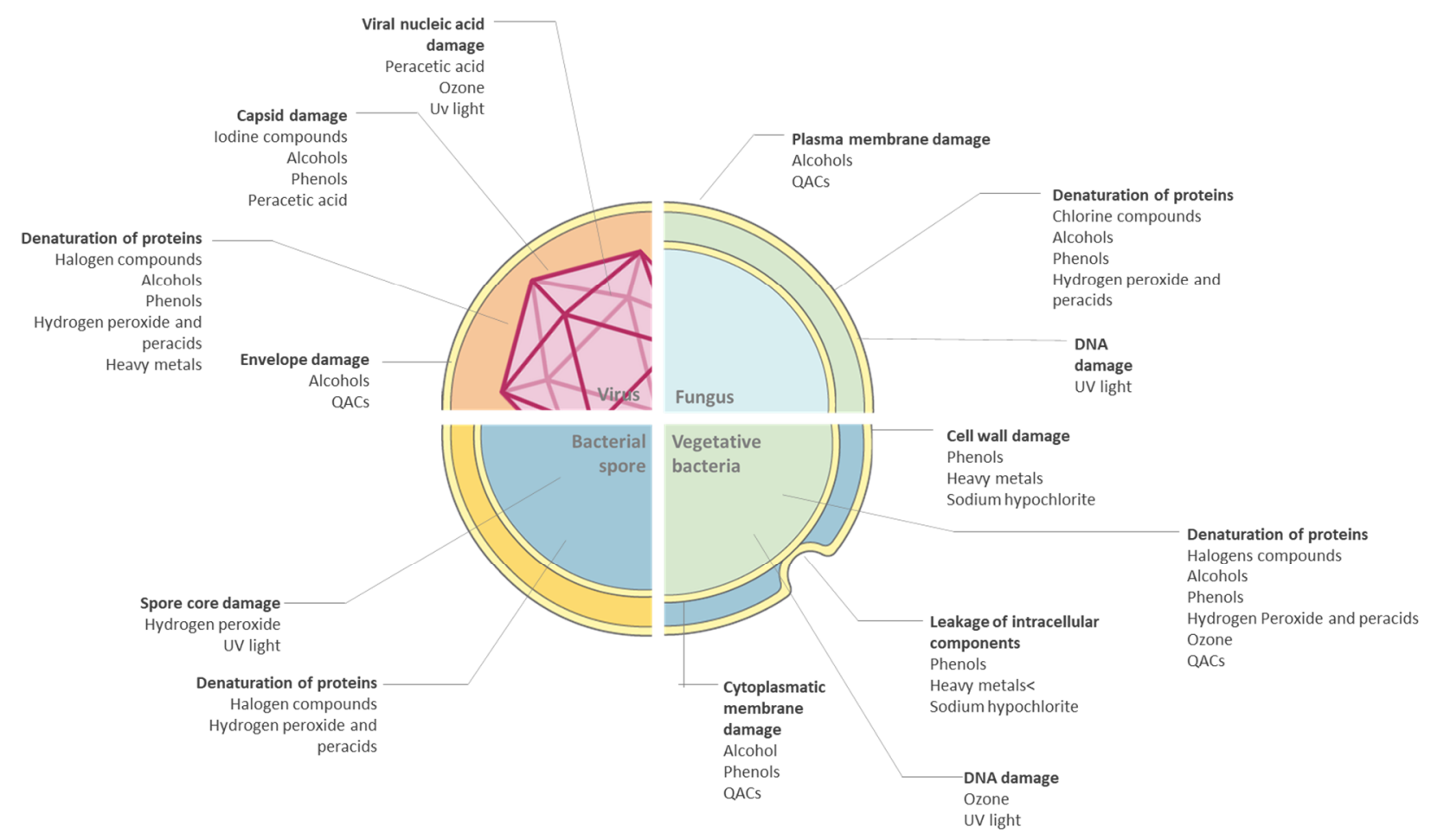

Figure 5. Mechanisms of biocide actions on microorganisms.

\subsection{Halogens}

\subsubsection{Chlorine Compounds}

Historically, the most widely used antimicrobial agents belonging to halogens are chlorine and chlorine releasing compounds.

Since elemental chlorine gas $\left(\mathrm{Cl}_{2}\right)$ is hazardous it must be banned either from workplaces or household environment and substituted by chlorine-releasing agents.

The most commonly used chlorine-releasing agent is sodium hypochlorite $(\mathrm{NaOCl})$, universally known as bleach, which is characterized by high microbicidal efficacy, low toxicity to humans, and low cost, but suffers the disadvantages of being irritant and corrosive. Nevertheless, ceramics, methylacrylate, or cement are not sensitive to bleach. More specifically, sodium hypochlorite is potentially bactericidal, virucidal, fungicidal, mycobactericidal, sporicidal. Hence it plays an important role in the surface disinfection of healthcare facilities and medical equipment.

The concentration of sodium hypochlorite sold for domestic purposes is around $5-6 \%$, with a $\mathrm{pH}$ around 11 and it is irritant; while in higher concentration, 10-15\%, with a pH around 13, it burns and it is corrosive. According to the Laboratory biosafety manual [32] published by the World Health Organisation (WHO): "A general all-purpose laboratory disinfectant should have a concentration of $1 \mathrm{~g} / \mathrm{L}$ available chlorine. A stronger solution, containing $5 \mathrm{~g} / \mathrm{L}$ available chlorine, is recommended for dealing with biohazardous spillage and in the presence of large amounts of organic matter. Sodium hypochlorite solutions, as domestic bleach, contain 50 $g / L$ available chlorine and should therefore be diluted 1:50 or 1:10 to obtain final concentrations of $1 \mathrm{~g} / \mathrm{L}$ and $5 \mathrm{~g} / \mathrm{L}$, respectively. [ . . . ] Surfaces can be decontaminated using a solution of sodium hypochlorite ( $\mathrm{NaOCl}$ ); a solution containing $1 \mathrm{~g} / \mathrm{L}$ available chlorine may be suitable for general environmental sanitation, but stronger solutions $(5 \mathrm{~g} / \mathrm{L})$ are recommended when dealing with high-risk situations."

Once sodium hypochlorite dissolves in water (Equations (1)-(3)) the two compounds that cause disinfection via oxidation are generated, namely hypochlorite ion $\left(\mathrm{OCl}^{-}\right)$, a weak base, and its corresponding acid, hypochlorous acid ( $\mathrm{HOCl})$, whose percentage is determined by water's $\mathrm{pH}$ and which is the most active between the two [33,34]. In fact, 
hypochlorous acid, due to no electronic charge, better penetrate the microorganism cell wall or any protective layer and effectively kills them by oxidating the side chains of proteins' amino acids $[35,36]$.

$$
\begin{gathered}
\mathrm{OCl}^{-}+\mathrm{H}_{2} \mathrm{O} \leftrightarrows \mathrm{HOCl}+\mathrm{OH}^{-} \\
\mathrm{HOCl}+\mathrm{H}^{+}+\mathrm{Cl}^{-} \leftrightarrows \mathrm{Cl}_{2}+\mathrm{H}_{2} \mathrm{O} \\
2 \mathrm{HOCl}+\mathrm{OCl}^{-} \rightarrow \mathrm{ClO}_{3}^{-}+2 \mathrm{Cl}^{-}+\mathrm{H}^{+}
\end{gathered}
$$

It is also common to express the concentration of chlorine compounds in terms of available chlorine or free available chlorine (FAC). The term FAC refers to the mixture of oxidizing chlorine forms that have a chlorine atom in the 0 or -1 oxidation state and are not combined with ammonia or organic nitrogen.

Sodium hypochlorite is characterized by high instability, therefore the FAC value is not so significant: 0.75 grams of activated chlorine evaporate per day. This happens not only when sodium hypochlorite gets heated up, but also when gets in touch with acids, sunlight, specific metals, toxic and corrosive gases, included chlorine itself [37,38].

Sodium hypochlorite solution is an inflammable weak base and these characteristics must be considered during its use and storage. Because of these reasons, formulation and conditions for the application should minimize the formation of by-products and even chloramines [39]. The overall stoichiometry of degradation is shown in Equation (3).

Thus disinfection's efficacy of chlorine releasing agents depends on the water's $\mathrm{pH}$ and FAC. Chlorine disinfection against vegetative bacteria, fungi, and yeast, as well as fungal conidia and viruses, is preferable at alkaline $\mathrm{NaOCl}$ solutions; although the germicidal efficacy is even greater when $\mathrm{pH}$ value is around 5.5 and $8[39,40]$. Furthermore, Kuroiwa et al. [41] proved that adjusting the $\mathrm{pH}$ around 5 by weak acidification with acetic acid, resulted in a shortened killing time of all the B. subtilis JCM1465 spores by one-third. On the contrary, this preparation killed all of the non-spore-forming bacteria within 30 seconds as quickly as $\mathrm{NaClO}$ solution without acidification. The importance of the $\mathrm{pH}$ level is shown in Figure 6. At a pH of 7, the concentration of hypochlorous acid is $80 \%$, while when the $\mathrm{pH}$ value is around 8 , the concentration drops to $20 \%$.

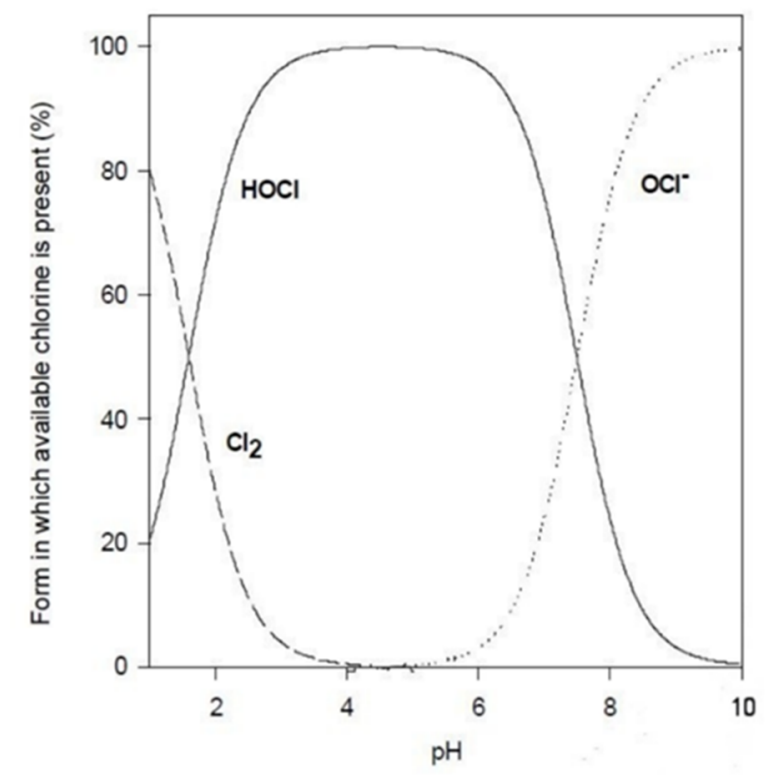

Figure 6. Active chlorine species concentration at different $\mathrm{pH}$ values [42].

The $\mathrm{pH}$ value of the solution is fundamental either for the bactericidal activity or for the shelf life: at $25-35^{\circ} \mathrm{C}$, neutralized- $\mathrm{NaOCl}$ solutions ( $\mathrm{pH}$ 7) expires in a few hours, generated $\mathrm{NaOCl}(\mathrm{gNaOCl})$ solutions (produced by electrolysis of a salt $(\mathrm{NaCl}$ solution, $\mathrm{pH}$ 9) last 6 days, while stabilized $\mathrm{NaOCl}$ solutions ( $\mathrm{pH} 9-11)$ persist more than 30 days [43]. 
Sodium hypochlorite is widely used, not only as a surface antimicrobial but also in water treatment, water disinfection, and bleaching in the textile industry. Furthermore, it can be used to avoid crustaceans and algae formation in cooling towers.

As an alternative, calcium hypoclorite $\left(\mathrm{Ca}(\mathrm{OCl})_{2}\right)$ also known as $\mathrm{HTH}$ (high test hypochlorite) can be used as well. HTH is sold in granular form that, once in solution, achieves a $\mathrm{pH}$ of 9-11 and it is as stable as $\mathrm{NaOCl}$ [43].

Another chlorine releasing agent that has been explored as an alternative to sodium, or calcium, hypochlorite is sodium dichloroisocyanurate $(\mathrm{NaDCC})$. This compound is the sodium salt of a chlorinated hydroxytriazine (Figure 7).<smiles>N#[Y9]n1c(=O)n(Cl)c(=O)n(Cl)c1=O</smiles>

Figure 7. Structure of sodium dichloroisocyanurate (NaDCC).

This disinfectant is available as a stable powder that produces solutions that have a $\mathrm{pH}$ level of around 6 and expire within hours [43]. These solutions are more susceptible to inactivation by organic matter than $\mathrm{NaOCl}$ [44-46]. NaDCC is often used as a broadspectrum disinfectant since it has been reported to generally achieve similar disinfection activities to chlorine, while results to be less corrosive. On stainless steel, Bloomfield et al. [47] reported lower ME (microbiocidal effect) values following a 5-min exposure to $250 \mathrm{ppm} \mathrm{NaDCC}$ compared to $\mathrm{NaOCl}$ at the same concentration against $S$. aureus ( 2.4 vs. 4.9 to $<6.2 \log$ reduction), Pseudomonas aeruginosa (3.7 vs. 3.7-4.3 log reduction), and Enterococcus faecium (2.2 vs. $3.1 \mathrm{log}$ reduction). At $2500 \mathrm{ppm}$, both $\mathrm{NaDCC}$ and $\mathrm{NaOCl}$ achieved at least a $6 \log$ reduction in each tested organism. Gallandat et al. [48] observed similar efficacies of $\mathrm{NaOCl}, \mathrm{gNaOCl}, \mathrm{NaDCC}$, and $\mathrm{HTH}$ (5000 ppm) against both E. coli and Pseudomonas phage Phi6 after 10-15 min on several nonporous surfaces, with minimum 5.9 and $3.1 \log$ reductions, respectively. At higher concentrations, Aarnisalo et al. [49] observed 3.1 and $0.5 \log$ reductions (without/with $2 \%$ pork meat) in Listeria monocytogene after $30 \mathrm{~s}$ exposure to $0.04 \%(w / v)$ NaDCC and $>3.6$ and $0.3 \log$ reductions (without/with $2 \%$ pork meat) after 30 seconds exposure to $0.2 \%(w / v) \mathrm{NaOCl}$. Interestingly, the entry containing hypochlorite as an antibacterial agent and anionactive tensides as cleaning compounds were considered to be much more efficient (3.8 and 2.2 log reductions, without/with $2 \%$ pork meat) than the hypochlorite disinfectant, probably due to the inactivation of the $\mathrm{NaOCl}$ by the organic matter.

To be effective against bacteria and spores, an adequate concentration of $\mathrm{HOCl}$ is required; in Table 4 are reported the recommended dilutions of each chlorine releasing compound mentioned until now to significantly reduce the risk of transmission. The surface conditions, the main advantages, and drawbacks have also been considered.

\subsubsection{Iodine Compounds}

Although less reactive than chlorine, iodine solution has a broad spectrum of antimicrobial activity against both gram-negative and gram-positive bacteria, fungi, protozoa, and even bacterial spores [12], while it is not so effective as virucidal [50]. Many investigations identified elemental iodine $\mathrm{I}_{2}$ and hypoiodous acid (HIO) as the two most powerful antimicrobials agents among the several iodine species.

$$
\begin{aligned}
\mathrm{I}_{2}+\mathrm{H}_{2} \mathrm{O} & \leftrightarrows \mathrm{HIO}+\mathrm{I}^{-}+\mathrm{H}^{+} \\
\mathrm{HIO} & \leftrightarrows \mathrm{IO}^{-}+\mathrm{H}^{+} \\
3 \mathrm{HIO}+3 \mathrm{OH} & \leftrightarrows \mathrm{IO}_{3}^{-}+2 \mathrm{I}^{-}+3 \mathrm{H}_{2} \mathrm{O}
\end{aligned}
$$


Table 4. Recommended dilutions of commonly used chlorine releasing compounds.

\begin{tabular}{|c|c|c|c|c|}
\hline \multirow{2}{*}{ Chlorine Type } & \multicolumn{2}{|c|}{ Use Condition } & \multirow{2}{*}{ Advantages } & \multirow{2}{*}{ Disadvantages } \\
\hline & Clean Condition & Dirty Condition & & \\
\hline $\begin{array}{l}\text { Sodium hypochlorite } \\
\text { solution ( } 5 \% \text { available } \\
\text { chlorine) }\end{array}$ & $20 \mathrm{~mL} / \mathrm{L}$ & $100 \mathrm{~mL} / \mathrm{L}$ & $\begin{array}{l}\text { Can be local (stabilized form) } \\
\text { Can be on-side } \\
\text { (no stabilized form) } \\
\text { Does not clog pipes }\end{array}$ & $\begin{array}{l}\text { Shorter shelf life } \\
\text { Difficult to ship } \\
\text { Low stability } \\
\text { (no stabilized form) }\end{array}$ \\
\hline $\begin{array}{l}\text { High-test hypochlorite } \\
\text { (70\% available chlorine) }\end{array}$ & $1.4 \mathrm{~g} / \mathrm{L}$ & $7.0 \mathrm{~g} / \mathrm{L}$ & $\begin{array}{l}\text { Easy to ship } \\
\text { Long shelf life }\end{array}$ & Explosive \\
\hline $\begin{array}{c}\text { Sodium } \\
\text { dichloroisocyanurate } \\
\text { powder ( } 60 \% \text { available } \\
\text { chlorine) }\end{array}$ & $1.7 \mathrm{~g} / \mathrm{L}$ & $8.5 \mathrm{~g} / \mathrm{L}$ & $\begin{array}{l}\text { Easy to ship } \\
\text { Long shelf life } \\
\text { Does not clog pipes }\end{array}$ & Smell \\
\hline $\begin{array}{l}\text { Sodium } \\
\text { dichloroisocyanurate } \\
\text { tablets ( } 1.5 \mathrm{~g} \text { available } \\
\text { chlorine per tablet) }\end{array}$ & 1 tablet per $\mathrm{L}$ & 4 tablets per $\mathrm{L}$ & $\begin{array}{c}\text { Easy to ship } \\
\text { Long shelf life } \\
\text { Does not clog pipes }\end{array}$ & Smell \\
\hline
\end{tabular}

The dissociation constant of hypoiodous acid is $4.5 \times 10^{-13}$ and it reveals that the formation of hypoiodite ion $\left(\mathrm{IO}^{-}\right)$in an aqueous solution is insignificant. The percentages of the species (see Equations (4)-(6)) are directly related to the $\mathrm{pH}$ level of the solution and, to a much lesser extent, to the temperature.

Figure 8 shows $\mathrm{I}_{2}$ hydrolysis data at different $\mathrm{pH}$ values and it is clear that the highest concentrations of the antimicrobial species are present in the acid range. In fact, when the solution is alkaline, several iodine species that have no apparent antimicrobial activity can also be generated. Iodate formation could not be a problem if the $\mathrm{pH}$ value stays below 8 and the contact time of disinfection is accomplished in the first $30 \mathrm{~min}$.

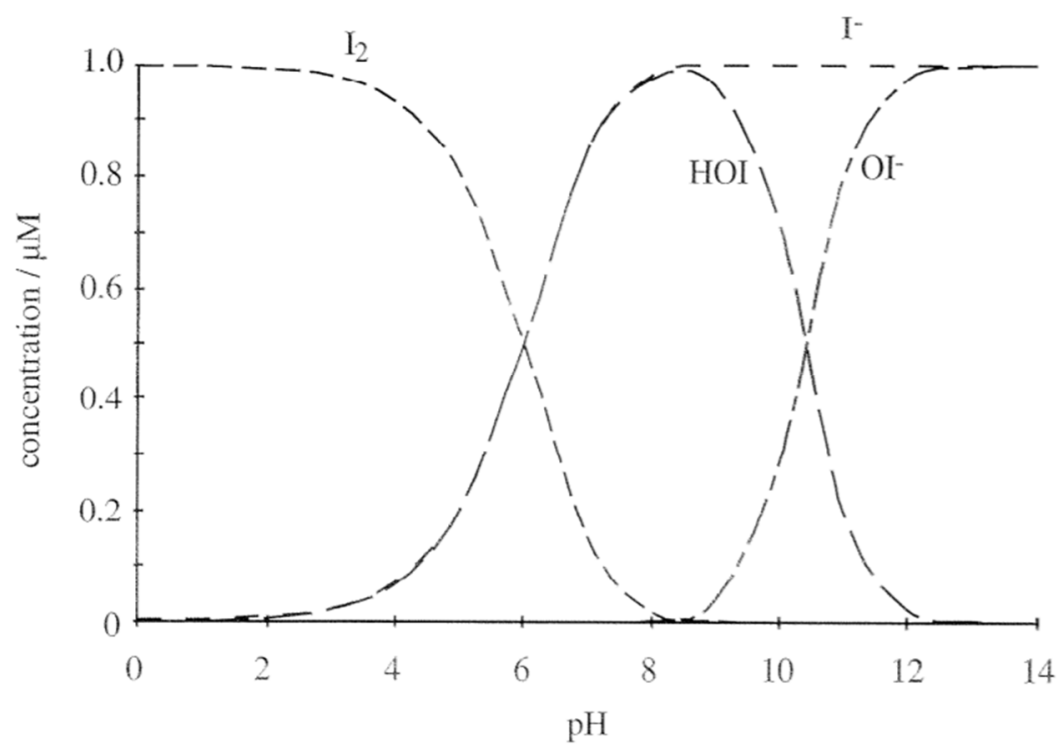

Figure 8. pH-dependent speciation of iodine [51].

Historically iodine solutions or tinctures have been primarily used by health professionals as antiseptics on skin or tissue. Unfortunately, aqueous solutions are generally unstable so a combination of iodine and a solubilizing agent or carrier has been formulated. These combinations, called iodophor, have been used both as antiseptics and disinfectants, retaining the germicidal efficacy of iodine but being more stable and relatively free of toxicity and irritancy [39]. They have been developed to slowly release iodine $\left(\mathrm{I}_{2}\right)$ from the 
complex, which can be a cationic surfactant, non-ionic, polyoxymer, or polyvinylpyrrolidone [52].

The most known and widely used iodophor is povidone-iodine, Figure 9. Regarding this complex, Block et al. observed 3.14, 3.49, 3.47, and 3.78 log reduction, after $1.5 \mathrm{~min}$ for VRE, E. faecalis, and methicillin-resistant and methicillin-sensitive S. aureus, respectively [53].

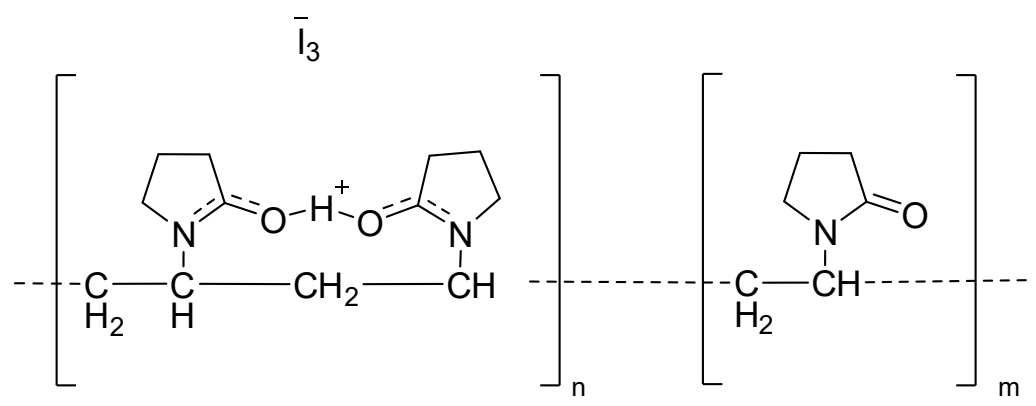

Figure 9. Structure of povidone-iodine complex.

Surfactant iodophor, when used, may add a further detergency activity, even though iodine is chemically less reactive than chlorine. Moreover, surfactant iodophor is less affected by the presence of organic matter than chlorine.

An iodophor, when used at $25 \mathrm{ppm}$ (parts per million of available iodine), is considered to act as a sanitizer, however, when the same product is applied at $75 \mathrm{ppm}$ falls into the disinfectant category.

After its release, iodine can quickly penetrate the cell wall of a microorganism and oxidize thiol groups leading to disruption of proteins and nucleic acids structures [39].

\subsection{Alcohols}

\subsubsection{Alifatic Alcohols}

Among the several aliphatic alcohols that exhibit microbicidal properties ethyl alcohol (ethanol), isopropyl alcohol (isopropanol, propan-2-ol), and $n$-propanol are the most commonly used (Figure 10).<smiles>CCO</smiles>

Ethanol

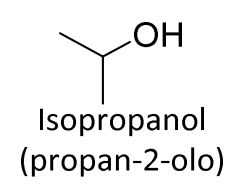

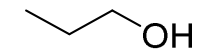

n-propanol

(propan-1-olo)

Figure 10. Antimicrobial alcohols.

These disinfectants are rapid bactericidal rather than bacteriostatic against vegetative bacteria, included mycobacteria but have no effect on spores. The bactericidal properties of ethanol were examined against several microorganisms for different ranges of time [54]: P. aeruginosa, Serratia marcescens, E. coli, and Salmonella typhy were killed in $10 \mathrm{~s}$ by all concentrations of ethanol from $40 \%$ to $100 \%$ ( $30 \%$ for the E.coli entry). S. aureus and Streptococcus pyogenes were slightly more resistant, being killed in $10 \mathrm{~s}$ with concentrations of $60 \%-95 \%$. Isopropyl alcohol resulted slightly more bactericidal than ethyl alcohol for E. coli and S. aureus [55]. Furthermore, this category of biocides shows limited fungicidal and virucidal activity especially on lipophilic viruses such as herpes virus, influenza virus, and hepatitis B and C viruses [56,57]. Literature data demonstrate that isopropyl alcohol shows its antimicrobial activity against lipid viruses but it is not active against the nonlipid enteroviruses [58]

These alcohols exert their antimicrobial activity by causing protein denaturation [59,60]. Water plays an important role in the formulation of alcoholic disinfectants because, in its 
absence, proteins are not readily denatured by alcohol. Therefore a 70\% solution of alcohol is a much more effective sanitizer than the pure (99\%) product [61], but when the concentration drops below $50 \%$ there is no practical value [62]. Concentration can be expressed both by weight/weight percentage $(\% w / w)$ and, most frequently, by volume/volume percentage $(\% v / v)$. This value is important since it is linked to the evaporation rate: a higher concentration of alcohol evaporates quickly. The evaporation speed could be an issue if a longer contact time is requested, but the addition of surfactants [63], or combination with alkali, mineral acids, and hydrogen peroxide could overcome this problem [12,24].

Alcohols are fast-acting, easy to use but are not free from limitations that are due to poor detergent properties, toxicity, and, of course, their flammability, which is a big concern. The minimum temperature at which vapors above a volatile combustible substance ignite in air when exposed to flame defines the flashpoint. The higher the concentration, the lower the flashpoint. For example, the flashpoints of $70 \%$ ethyl and $70 \%$ isopropyl alcohol are $20.5^{\circ} \mathrm{C}$ and $21.0^{\circ} \mathrm{C}$, respectively, while the flashpoint of $30 \%$ ethyl alcohol is $29^{\circ} \mathrm{C}$ [64] Moreover, even if alcoholic disinfectants are neither corrosive nor staining, they could damage some instruments, by swelling or hardening rubber.

\subsubsection{Aromatic Alcohols}

Besides aliphatic alcohols, also aromatic ones exhibit antimicrobial properties being effective in sanitization and disinfection, even in the presence of biological fluids. Phenols are the reference standard for the Rideal-Walker (RW) and Chick-Martin tests for disinfectant evaluation [65].

Phenol $\left(\mathrm{C}_{6} \mathrm{H}_{5} \mathrm{OH}\right)$ is an organic compound that consists of a benzene ring bearing a single hydroxy substituent. It appears as a white crystalline solid, which is partially watersoluble (1 $\mathrm{g} / 15 \mathrm{~mL}$ water) [66] and it has a $\mathrm{pK}_{\mathrm{a}}$ value of 10 , which means it is classified as a weak acid.

Phenol exerts its antimicrobial activity against vegetative bacteria, both Gram-positive and negative, fungi and viruses but it is not so effective as sporicidal and against acid-fast bacteria.

The biological activity is related to the undissociated molecule, which induces progressive leakage of essential metabolites, including the release of $\mathrm{K}^{+}$[67], leading to membrane damage and consequentially cell lysis, while acting like a protoplasmic poison causing coagulation of the cytoplasm [68].

Phenol is the parent compound but the chemical structure can be modified by replacing one of the hydrogens on the aromatic ring with a different functional group (halogen, alkyl, phenyl, benzyl, etc.). Figure 11 represents several microbicidal phenols.

The structure-activity relationship in the phenol series was investigated by Suter [69]. Regarding the results, it is interesting to notice that the microbiocidal activity increases in derivatives with alkyl chain in the para position, constituted by a maximum of six carbon atoms, since for longer chain the activity drops probably due to the decrease of water solubility. Nitrophenols were evaluated as well; unfortunately, the toxicity increased towards both bacteria and humans and there is also a trend to be inactivated by organic matter. Finally, bisphenolic compounds show activity if they are connected by a methyl linker, sulfur, or oxygen atom, and even if they are directly linked. Augmentation of the efficacy can also be achieved by halogen substitutions.

Among all the derivatives, o-phenylphenol and 2-benzyl-4-chlorophenol are widely used as healthcare disinfectants.

As disclosed by published reports, commonly used phenolic compounds show, at their use dilution, antimicrobial efficacy against bacteria, fungi, viruses, including HIV [70-73]. However, literature reports also that the phenolic disinfectants 'Stericol' and 'Lysol' show a limited effect on Coxsackie B4, Enterovirus 11, and Poliovirus [74]. 
<smiles>CC(C)(C)CC(C)(C)c1ccc(O)cc1</smiles>

p-t-octylphenol

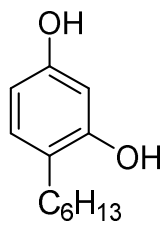

4-hexylresorcinol<smiles>Cc1ccc(-c2ccccc2)c(O)c1</smiles>

o-phenylphenol<smiles>Oc1ccccc1Cl</smiles>

2-chlorophenol<smiles>Oc1ccc(Cl)cc1</smiles>

4-chlorophenol<smiles>Oc1cc(Cl)c(Cl)cc1Cl</smiles>

2,4,5-trichlorophenol<smiles>Oc1c(Cl)c(Cl)c(Cl)c(Cl)c1Cl</smiles>

pentachlorophenol<smiles>Cc1cc(O)ccc1Cl</smiles>

chlorocresol (4-chlor-3-methylphenol)<smiles>Cc1cc(O)cc(C)c1Cl</smiles>

chloroxylenol (4-chlor-3,5-dimethylphenol)<smiles>Cc1cc(O)c(Cl)c(C)c1Cl</smiles>

dichlorometaxylenol (2,4-dichlor-3,5-dimethylphenol)<smiles>Oc1ccc(Cl)cc1-c1ccccc1</smiles>

4-chloro-2-phenylphenol<smiles>Oc1ccc(Cl)cc1Br</smiles>

2-benzyl-4-chlorophenol

Figure 11. Several microbiocidal phenols.

Phenols react with certain types of plastic surfaces and are adsorbed by porous material. If not rinsed thoroughly with water, the alcohol residue can cause skin irritation or depigmentation [75]. Moreover, another disadvantage is that phenols are quite expensive, and literature reports demonstrated that they are associated with idiopathic neonatal hyperbilirubinemia in infants $[76,77]$.

\subsection{Quaternary Ammonium Compounds (QACs)}

Quaternary ammonium compounds (QACs) may be considered as amphiphilic substituted compounds, which carry a permanent positively charged nitrogen, counterbalanced by a halide or sulfate moiety. QACs are classified according to the nitrogen substituents, which can include either the type of the carbon chains or the presence of aromatic moieties (Figure 12). The numerous investigations on these chemical structures have increased efficacy while reducing costs.

Demand for these disinfectant agents has increased over the decades, furthermore, their use is not only limited as a germicidal, but they have been widely used also in a variety of industrial, agricultural, clinical applications, and consumer products [78-81]. 

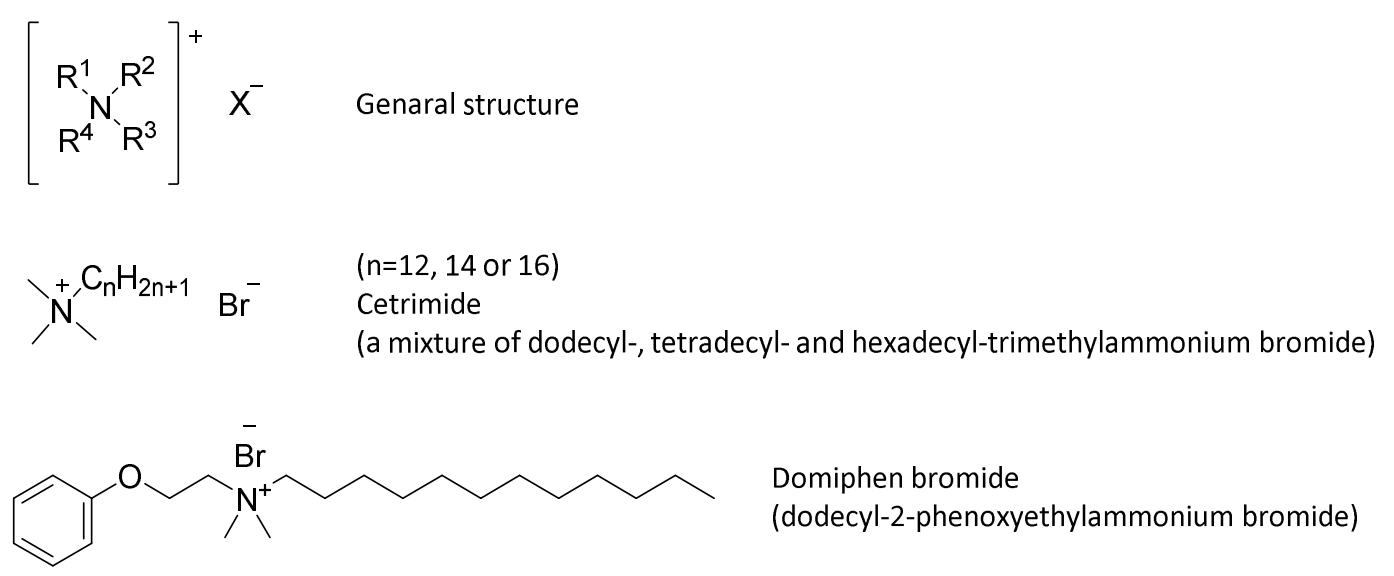<smiles>CC(C)(C)CC(C)(C)c1ccc(OCCOCC[N+](C)(C)Cc2ccccc2)cc1</smiles>

Benzethonium chloride (benzyldimethyl-2-\{2-[4-(1,1,3,3-tetramethylbutyl)phenoxy]ethoxy\}-ethylammonium chloride
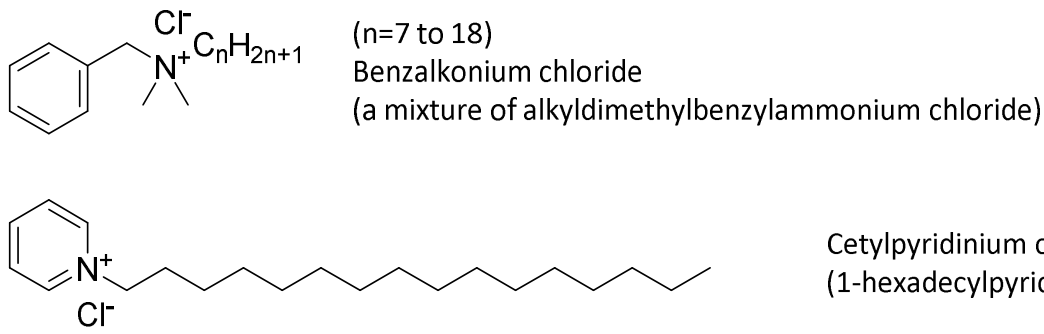

Cetylpyridinium chloride (1-hexadecylpyridinium chloride)

Figure 12. General structure and common QACs.

Their microbicidal activity is due to their adsorption on proteins or acidic phospholipids in the membrane that leads to the formation of hydrophilic voids. The denaturation of essential cell protein causes cytoplasmic membrane permeability and eventually leads to cell disruption [82]. QACs seems also to be involved in the inactivation of energy-producing enzymes, furthermore, they can bind to DNA [83].

Their hydrophobic activity makes them more effective against lipophilic microorganisms. Therefore QACs are solid bactericidal agents, especially against Gram-positive bacteria, and virucidal against enveloped viruses (e.g., herpes simplex, adenovirus, vaccinia) whilst they are not sporicidal and generally not tuberculocidal or virucidal against hydrophilic viruses [84].

QACs are commonly used in ordinary environmental sanitation of noncritical surfaces, such as floors, furniture, and walls. Scientific literature reports that quaternary ammoniumbased disinfectants are effective in removing and/or inactivating S. aureus and P. aeruginosa from computer keyboards, while are not so active against VRE species [85]. Moreover, a recent work by Brown et al. [86] demonstrated that the microbial reduction due to QAC's activity on glass continues after contact and wetness time.

However, it is important to point up that the efficacy is influenced not only by the compound and surface combinations but even by the product formulation and the water hardness [87]. Indeed, anionic surfactants and high mineral content could lead to insoluble precipitates. Therefore, QAC's formulation is restricted to nonionic or zwitterionic surfactants, which typically are less effective as cleaning ingredients. Furthermore, some materials, like cellulose-based wipers and gauze pads, absorb these actives, lowering the microbiocidal efficacy [88]. On the other hand, QACs have many advantages like high stability, low color, odorless, and relatively low toxicity (unlike phenols and chlorine bleach). 
Nevertheless, spraying or fumigation of this chemical disinfectant is not recommended because a few cases disclose occupational asthma as a result of exposure [89-91]. When used, these disinfectant agents are often applied with a cloth or wipe that has been soaked in disinfectant, which may contain mixtures of QACs. Benzalkonium chloride (BAC) is one of the most extensively applied QACs, especially in surface disinfection [92]. BAC's concentration is usually between 0.01 and $1 \%$ but can rise at $15 \%$ [93]. Other QACs found in disinfection products have similar concentrations.

\subsection{Hydrogen Peroxide and Peracids}

Over the years, hydrogen peroxide $\left(\mathrm{H}_{2} \mathrm{O}_{2}, \mathrm{HP}\right)$, represented in Figure 13 , has extensively been recognized to have antimicrobial properties against a wide variety of microorganisms, such as bacteria, viruses, spores, and fungi [94,95]. The mechanism involved in the antibacterial effect of HP ascribes to the release of oxygen free radicals (hydroxyl radical). These radicals are potent oxidizing agents that can quickly react with bacterial biomolecules, such as thiol groups of proteins, causing irreversible structural modifications and subsequent cellular death [96]. HP represents one of the most used biocides for different antimicrobial applications, such as disinfection and sterilization, and is colorless and odorless, and associated with low ecotoxicity. It is a versatile disinfectant, due to the possible employ in several environments including air, water, and surfaces [97].<smiles>OO</smiles>

Hydrogen peroxide<smiles>CC(=O)OO</smiles>

Peracetic acid<smiles>O=COO</smiles>

Performic acid

Figure 13. Structures of biocides peroxigen compounds.

The most employed formulations of hydrogen peroxide are liquid and gas. Hydrogen peroxide liquid formulations are widely used for sterilization and disinfection processes. Usually, a $6 \%$ aqueous solution of hydrogen peroxide is employed for laboratory surface cleaning, but its bactericidal and sporicidal efficacy is lower against resistant bacterial spores and protozoan cysts, because of the short exposure time [98]. Hydrogen peroxide solutions are unstable thus suitable stabilizing agents such as benzoic acid are usually added. On the other hand, the production of non-toxic and biodegradable decomposition products (oxygen and water) emerges as an important advantage compared to other disinfectants [99].

Many studies revealed the effectiveness of the vaporized form of HP (HPV) for surface disinfection [100]. This system inactivates nonenveloped viruses, mycobacteria, and some multidrug-resistant microorganisms present in hospital room surfaces, reducing the number of contaminated porous and nonporous surfaces to 5-0\% [101]. In particular, HPV resulted to be efficient against enteric and respiratory pathogens, including adenovirus type 5, poliovirus Sabin 1, rotavirus SA11, but also Mycobacterium tuberculosis and C. difficile spores [102]. In addition, HPV is often found in combination with heavy metals like silver ions, which showed an interesting bactericidal activity, resulting as a useful agent for surface disinfection in hospital settings $[95,97]$. The hydrogen peroxide solution in nebulization systems was also evaluated for surface disinfection. It provides a better decrease of microbial contamination on vertical surfaces compared to horizontal ones. However, the use of aerosol form is limited to the hospital's empty spaces, excluding patient rooms, intensive care units, and other occupied areas [103].

Peracetic acid $\left(\mathrm{CH}_{3} \mathrm{COOOH}\right)$, Figure 13 , is an organic peroxide with activity against mycobacteria, viruses, spores, molds at low concentrations. It results to be a more potent antimicrobial agent than hydrogen peroxide [104,105]. Peracetic acid is a strong oxidizing agent that provides innocuous decompositions by-products: acetic acid and hydrogen peroxide. Generally, it is employed as a surface disinfectant and for medical device 
sterilization [106]. A 15\% aqueous solution of a mixture of peracetic acid, acetic acid, hydrogen peroxide, and water is commonly commercially available for the application as a disinfectant [99].

Figure 13 reports also performic acid $\left(\mathrm{CH}_{2} \mathrm{O}_{3}\right)$, which is another well-known disinfectant characterized by virucidal, bactericidal, sporicidal, and fungicidal activity, useful in hospital environments and the food industry [107]. In a similar way to peracetic acid, performic acid liquid formulation includes formic acid, hydrogen peroxide, and water, with the production of non-toxic by-products. The main limit of performic acid solution application is due to its instability, which requires instant preparation before use [108].

\subsection{Ozone}

Ozone $\left(\mathrm{O}_{3}\right)$ is an inorganic gas, an allotropic form of oxygen, that represents one of the most potent oxidizing agents, mainly used for the disinfection of water systems but also for the decontamination of surfaces in healthcare settings and medical industries [109-111]. Ozone effectively inactivates bacteria, viruses, molds, and protozoa by producing hydroxyl free radicals that can react with glycoproteins; disrupting the integrity of the cell membrane; oxidizing enzyme's thiol groups thus interfering with their activity; damaging DNA [112]. P. fluorescens, S. aureus, enteropathogenic E. coli, S. typhimurium, stomatitis virus, encephalomyocarditis virus, Vibrio cholerae, and Shigella flexneri are among the most sensitive microorganisms to the ozone treatment. Moreover, a quicker inactivation is observed when they are suspended in phosphate-buffered saline solutions [113].

$\mathrm{O}_{3}$ spontaneously decomposes into oxygen $\left(\mathrm{O}_{2}\right)$ and a single reactive oxygen atom, associated with antimicrobial activity. On the other hand, the use of the gaseous form for disinfection is not convenient for operator safety, due to the exposure time to high concentrations of the gas [114]. Ozone solutions in water (ozonated water) allow one to obtain a liquid form useful for safe and effective surface disinfection, even if its low stability limited the applications [112]. In fact, the aqueous form shows a short half-life at $20^{\circ} \mathrm{C}$, approximately $20-30 \mathrm{~min}$, after which it converts into an oxygen molecule; while the gaseous form results in having more stability and a longer half-life (12 h) [115]. The main aspects that affect ozone stability are temperature, $\mathrm{pH}$, and ozone-oxidizable materials. To reduce the decomposition rate of the gas, several ozone generators were designed to produce a stabilized form of aqueous $\mathrm{O}_{3}$ and to extend its half-life up to a few hours [114].

The effectiveness of aqueous and gaseous $\mathrm{O}_{3}$ against manure-based pathogens (MBP) were assessed for several contaminated surfaces. Aqueous ozone achieved a good reduction of MBP contamination on plastic and metal surfaces after 4 min of exposure, but not in more complex surfaces [112]. In a recent study, aqueous ozone demonstrated its efficacy also against several isolates of SARS-CoV-2 after $5 \mathrm{~min}$ of incubation, resulting in a new potential alternative for the disinfection of outdoor surfaces contaminated by this virus [114,116]. Synergistic effects have been shown between ozone and ultraviolet, hydrogen peroxide, or negative air ions, to increase the production of hydroxyl radicals and to improve the antimicrobial activity [117]. Zoutman et al. evaluated the efficacy of ozone in combination with hydrogen peroxide in vapor form for steel surface disinfection, demonstrating a high level of decontamination in short exposure time against the most common hospital-associated microorganisms [118]. The combination of $\mathrm{O}_{3}$ at low concentration and ultraviolet also demonstrated synergistic effects on E. coli and Escherichia virus MS2 inactivation, highlighting the potential antimicrobial properties of this mixture couple for the development of new disinfectants [119]. The use of ozone generators may be associated with the production of negative air ions (NAI) and nitrogen oxides that displayed bacteriostatic properties and a reduction of microbial populations, alone and in combination with the $\mathrm{O}_{3}[120]$. 


\subsection{UV}

Ultraviolet (UV) is electromagnetic radiation characterized by a wavelength from 10 to $400 \mathrm{~nm}$, longer than $X$-rays but shorter than visible light. Three bands of UV light have been identified: UVA ( $400-315 \mathrm{~nm})$, UVB (315-280 nm), and UVC (280-100 nm). UVC is also called ultraviolet germicidal irradiation (UVGI) for its antimicrobial properties [121]. In fact, for many years UV radiation has been employed for disinfection and sterilization, mainly the wavelength of $250 \mathrm{~nm}$ that has revealed better performance [122]. Nevertheless, different inactivation responses have been observed for several pathogens types including bacteria, viruses, fungi, and spores, even multidrug-resistant (MDR) strains of Acinetobacter baumannii, and C. difficile spores [123]. The efficacy of the decontamination is also related to the UVC amount and exposure time. For example, the best inactivation response for bacteria is at $254 \mathrm{~nm}$, while higher wavelengths are required for viruses and protozoa (260-270 nm) [124].

The mechanisms involved in the antimicrobial effects of UV light are based on photochemistry. Microorganism biomolecules, mainly nucleotides, absorb the photon energy emitted by UV light which causes chemical modifications and cellular damage through three potential routes: photohydration of DNA, photosplitting (breaking the DNA), or photodimerization [121]. Usually, when thymine bases adjacent to other ones are excited by a UV light, several covalently linked dimers are generated, blocking the DNA replication process. Anyway, UV is not able to kill microorganisms but make them unable to duplicate and induce infections [125].

During the years the use of several UVC light-based devices for cleaning and disinfection especially in hospital settings is increased because of its associated advantages, among which the absence of residues after treatment, the broad-spectrum activity, and rapid exposure times [126]. Today, mercury vapor arc lamps and xenon lamps represent the most frequently used UVC devices (100-280 nm). The first one emits a continuous UVC light at low pressure (approximately $254 \mathrm{~nm}$ ), while xenon lamps generate a pulsed light at high intensity [127]. However, UV irradiation at $254 \mathrm{~nm}$ can cause eyes and skin damages, so the treatment must be performed in unoccupied rooms. Alternatively, $222 \mathrm{~nm}$ UVC light could be used as it is poorly absorbed by the eyes and skin. Hiroki Kitagawa et al. validated the effectiveness of UVC radiation at $222 \mathrm{~nm}$ against SARS-CoV-2 contaminations, highlighting the possibility to carry out the disinfection process also in occupied rooms and spaces [128].

New technologies have been reported with the aim to improve the effectiveness of surface decontamination using UVGI. A novel portable UVC device has been assessed on several surfaces including plastic, bedrail, stainless steel, chrome-plated, and porcelain objects. A high level of bacterial inactivation has been observed against MRSA on the bedrail and against VRE on chrome and stainless steel [129]. Another study has described the efficacy of a new portable pulsed ultraviolet (UV) radiation generator for surface cleaning, towards the most common nosocomial bacteria, including P. aeruginosa, A. baumannii, S. aureus, and B. cereus. A potent antibacterial activity has been detected after a short exposure time, revealing an advantageous new method of sanitation $[130,131]$. Moreover, the UV technology leads to the development of the UVC reflective wall, aimed to reduce the time of irradiation. The exposure time decreases from 25 to $5 \mathrm{~min}$ for MRSA and 43 to $9 \mathrm{~min}$ for $C$. difficile spores if a UVC generator $(254 \mathrm{~nm})$ is located in a room coated by a specific reflective agent for UVC light [132].

The different mechanisms of action, the antimicrobial and cellular effects of the described antimicrobial agents are summarized in Table 5 together with the main advantages and disadvantages. 
Table 5. Summary of advantages and disadvantages of common surface disinfectant.

\begin{tabular}{|c|c|c|c|c|c|}
\hline Disinfectant & Mechanism of Action & Cellular Effect & Antimicrobial Effect & Advantages & Disadvantages \\
\hline Chlorine compounds & $\begin{array}{l}\text { Oxidation of side chains amino } \\
\text { acids in proteins }\end{array}$ & $\begin{array}{l}\text { Unfolding tertiary structure and } \\
\text { protein aggregation }\end{array}$ & $\begin{array}{l}\text { Bactericidal, fungicidal, } \\
\text { virucidal sporicidal }\end{array}$ & $\begin{array}{c}\text {-Not flammable } \\
\text {-Fast-acting } \\
\text {-Low-cost } \\
\text {-Resistant to water hardness } \\
\text {-Relatively stable }\end{array}$ & $\begin{array}{c}\text {-Salt residues } \\
\text {-Corrosive to metals } \\
\text {-Affected by organic matter } \\
\text {-Fabric discoloration } \\
\text {-Potential production of trihalomethane } \\
\text {-Irritating odor at high concentrations }\end{array}$ \\
\hline Iodine compounds & $\begin{array}{l}\text { Oxidation of thiol groups to } \\
\text { disulfides in proteins }\end{array}$ & $\begin{array}{l}\text { Modification of structural protein } \\
\text { and/or alterations in enzyme } \\
\text { activities }\end{array}$ & Bactericidal, virucidal & -Not flammable & $\begin{array}{l}\text {-Limited spectrum of activity } \\
\text {-Degradation of silicone catheters } \\
\text {-Staining for surfaces }\end{array}$ \\
\hline Alcohols & $\begin{array}{l}\text { Denaturation and precipitations } \\
\text { of cytoplasmic and membrane } \\
\text { proteins }\end{array}$ & $\begin{array}{l}\text { Alteration in metabolic processes, } \\
\text { membrane damage }\end{array}$ & $\begin{array}{c}\text { Bactericidal, fungicidal, } \\
\text { virucidal }\end{array}$ & $\begin{array}{c}\text {-Fast-acting } \\
\text {-Noncorrosive } \\
\text {-Nonstaining } \\
\text {-Suitable for small surfaces } \\
\text { disinfection }\end{array}$ & $\begin{array}{c}\text {-Not sporicidal } \\
\text {-Affected by organic matter } \\
\text {-No cleaning properties } \\
\text {-Deterioration of some instruments } \\
\text {-Flammable } \\
\text {-Rapid evaporation }\end{array}$ \\
\hline Phenols & $\begin{array}{l}\text { Denaturation of cytoplasmic and } \\
\text { membrane proteins }\end{array}$ & $\begin{array}{l}\text { Leakage of essential metabolites, } \\
\text { release of } \mathrm{K}^{+} \text {, membrane damage, } \\
\text { cytoplasmic coagulation }\end{array}$ & $\begin{array}{c}\text { Bactericidal, fungicidal, } \\
\text { virucidal }\end{array}$ & $\begin{array}{l}\text {-Low costs } \\
\text {-Not flammable } \\
\text {-Nonstaining }\end{array}$ & $\begin{array}{c}\text {-Rapid absorption by porous materials } \\
\text { and irritate tissues } \\
\text {-Potential depigmentation of skin } \\
\text {-Hyperbilirubinemia in infants }\end{array}$ \\
\hline $\begin{array}{l}\text { Hydrogen peroxide and } \\
\text { peracids }\end{array}$ & $\begin{array}{l}\text { Oxidation of thiol groups to } \\
\text { disulfides in proteins }\end{array}$ & $\begin{array}{l}\text { Modification of structural protein } \\
\text { and/or alterations in enzyme } \\
\text { activities }\end{array}$ & $\begin{array}{l}\text { Bactericidal, fungicidal, } \\
\text { virucidal }\end{array}$ & $\begin{array}{c}\text {-Fast-acting } \\
\text {-Safe for workers } \\
\text {-Non-toxic } \\
\text { by-products } \\
\text {-Surface compatible } \\
\text {-Nonstaining } \\
\text {-Odorless } \\
\text {-Not flammable }\end{array}$ & $\begin{array}{l}\text {-More expensive compared to other } \\
\text { disinfectants } \\
\text {-Not sporicidal at low concentrations }\end{array}$ \\
\hline Ozone & $\begin{array}{l}\text { Oxidation of thiol groups in } \\
\text { proteins and interaction with } \\
\text { purine and pyrimidine bases }\end{array}$ & $\begin{array}{l}\text { Modification of structural } \\
\text { protein, alterations in enzyme } \\
\text { activities, and/or DNA damages }\end{array}$ & $\begin{array}{l}\text { Bactericidal, moldicidal, } \\
\text { virucidal, protozocidal }\end{array}$ & -Fast-acting & $\begin{array}{l}\text {-Gaseous form not safe } \\
\text {-Low stability solutions form } \\
\text {-Reacted with organic matter }\end{array}$ \\
\hline UV light & $\begin{array}{l}\text { chemical modifications of } \\
\text { nucleotides caused by photon } \\
\text { energy emitted }\end{array}$ & $\begin{array}{c}\text { DNA damages (photohydration, } \\
\text { photosplitting, } \\
\text { photodimerization) }\end{array}$ & bacteria, fungi, viruses, spores & $\begin{array}{l}\text {-Absence of residues or } \\
\text { by-products } \\
\text {-Fast-acting }\end{array}$ & $\begin{array}{l}\text {-No microbiocidal effect } \\
\text {-Eyes and skin damages for UV } \\
\text { irradiation at 254-nm }\end{array}$ \\
\hline
\end{tabular}




\section{Antimicrobial Surfaces}

To date, several strategies have been proposed to prevent microorganisms from adhering to the surface or to kill the ones that manage to attach them. Furthermore, minimizing biofilm formation should be a further goal [133]. Nonetheless, it is necessary to take into account that bacterial colonization of surfaces is a key process of corrosion, infection, fermentation, and fouling [134].

New strategies to control and hopefully avoid the adhesion of microorganisms on surfaces (Figure 14) are inspired by nature, a source that appears to be almost unlimited, and it has attracted a large amount of interest in the past decades. Indeed a current trend is based on natural materials such as plant leaves and insect cuticles. For example, the leaves of Nelumbo nucifera, commonly known as lotus, exhibit superhydrophobicity, and self-cleaning abilities. The characteristics that afford this self-cleaning capability are the lipid layer that covered the surface. This results in a high water contact angle $\left(\theta>150^{\circ}\right)$ and a low tilting angle $\left(\theta<10^{\circ}\right)$, which are parameters needed to lead the water droplet to roll off [135]. In this way, the water droplets collect dirt as they move over the leaf. Many other plants exhibit very similar properties to that of the lotus leaf, Indian canna, taro, and cabbage leaves.

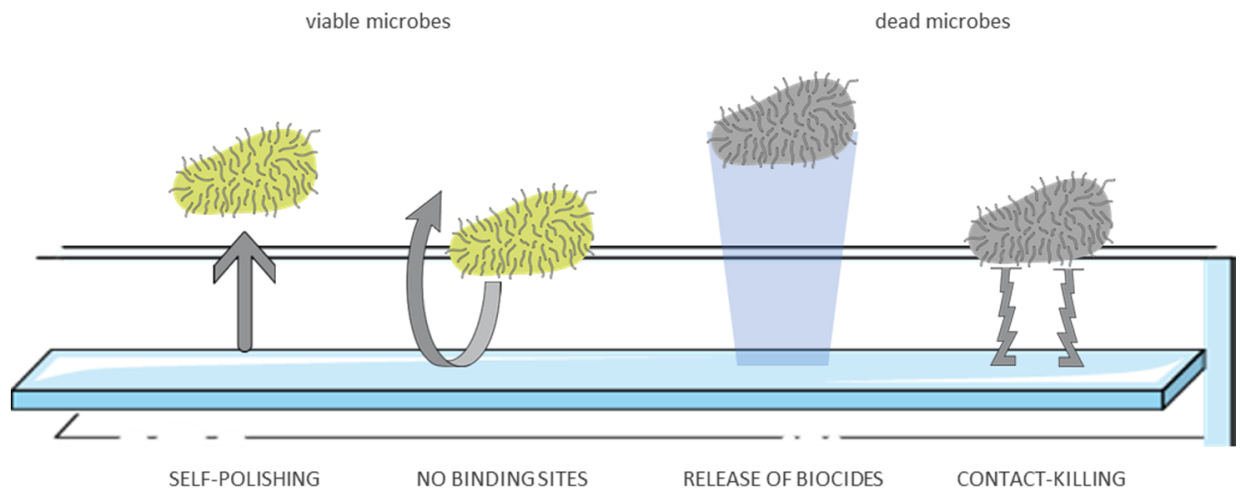

Figure 14. General classes of antimicrobial surfaces.

Similarly, insect surfaces are covered by a layer of lipophilic cuticle. Some insects, e.g., dragonflies or cicada, self-assemble this barrier into three-dimensional nanoarray structures, which enable air to be trapped in and hence exhibit a high water contact angle $[136,137]$. Furthermore, the turbulent conditions during their flight enhance these self-cleaning properties. Artificial surfaces can be produced to possess similar properties, causing water to behave in a similar way, therefore bacterial cells could be removed before they could adhere to the surface $[134,138]$.

Other interesting approaches use bio-functionalization or surface coatings to give or enhance antibacterial properties: solid heavy metals, such as silver [139,140], copper [141-143] or zinc [144,145], and its alloys have been widely used as antimicrobial agents for millennia due to their intrinsically strong antibacterial activity.

Usually, these approaches focus on a nano-size particulate form of the metal: a larger surface allows better contact with the target microbe cells while enabling a more efficient release of the particles. Among these materials, copper is one of the most frequently used due to its efficiency in "contact killing": microorganisms survive only a few minutes on these kinds of surfaces $[146,147]$. Obviously, the higher the copper concentration, the faster and more efficient is the antimicrobial activity. Nevertheless, to promote the activity other factors have to be taken into account: both extrinsic, such as protocols and operators, and intrinsic [148].

The major issue with the use of metallic ions is that their interactions are non-specific, which is a major concern from a biocompatibility and cytotoxicity point of view. Further- 
more, the leaching components may contaminate and accumulate in the environment, promoting bacteria's resistance.

Further studies are still required to find the best enhancing parameters like high temperature or high humidity, the metal's physical form, or coating techniques [149].

More recently, another innovative approach based on photosensitizer compounds has been developed for preventing bacterial colonization. These biocides exert their action after activation by a light source [150]. UVA-induced antimicrobial activity can also be achieved with metals [151,152]; the main mechanisms driving the activity are the formation of highly reactive species like superoxide and hydroxyl radicals and the slow release of metal ions.

The most common techniques that can be applied to incorporate biocides in the surface involve the impregnation of the antimicrobial into the coating. The simultaneous encapsulation of different antimicrobials in one matrix has proven to be more efficient than entrap only one [153]. The layer by layer (LbL) technique is another powerful strategy for surface engineering, which allows one to control the leaching characteristics of a biocide [154].

In addition, slow-releasing systems, release-on-command systems, and non-leaching systems have also been developed. Commonly employed polymers are polyoxazolines with methyl (PMOZ), ethyl (PEOZ), and propyl (PPOZ) [155], polyacrylamide [156], or poly ethylene glycol-PEG [157] ). It has been experimentally proven that antimicrobial properties are also shown by surfactant type polymers and some naturally derived polymers, like chitosan [158]. Different molecules used to chemically modify the surface are described in Figure 15. The building blocks of these polymers can differ in nature, molecular weight, and chain length. These are critical parameters that need to be optimized with other factors which may influence the effectiveness of the antimicrobial, like the surface charge density and the hydrophilic/hydrophobic balance.<smiles>[R]C(=O)N(CC)CCC</smiles>

Polyoxazolines

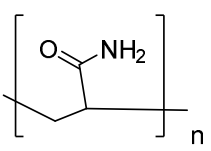

Polyacrylamide<smiles>OCCC(O)O</smiles>

Polyethyle oxide (PEO) Polyethylen glycol (PEG)

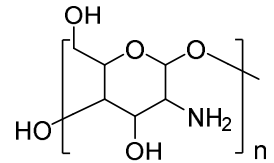

Chitosan

Figure 15. Chemical structure of some common monomers and polymers used for surface treatment.

The physical principle is that polymer brushes act as a steric barrier against bacterial attachment. Indeed some polymers provide an unfavorable surface for bacterial interaction, especially cationic polymers. They have shown effectiveness against bacterial infection but their long-term use discloses toxicity as a concern. Their mechanism totally relies on their charge that attracts and "captures" negatively charged bacterial cells, and this interaction damages the bacterial membrane, giving a bacteriostatic, and eventually a bactericidal effect.

To improve the antimicrobial efficacy several agents, such as small compounds, peptides, and enzymes, can be introduced into polymer molecules [159]. Probably, polymers of QACs represent the class that has received more attention over the years [160,161].

Ideally, a coating of the antimicrobial polymer must exhibit a broad antimicrobial spectrum in a brief contact time and it must remain effective over the lifespan's article while avoiding leaching into the environment or decomposition in toxic products. Furthermore, it shouldn't be toxic nor irritating to those who are handling it and not water-soluble (for water disinfection application) [162].

Figure 16 summarizes all the approaches that involve changes in the chemical and/or physical properties of the surface to have a biocide effect. 


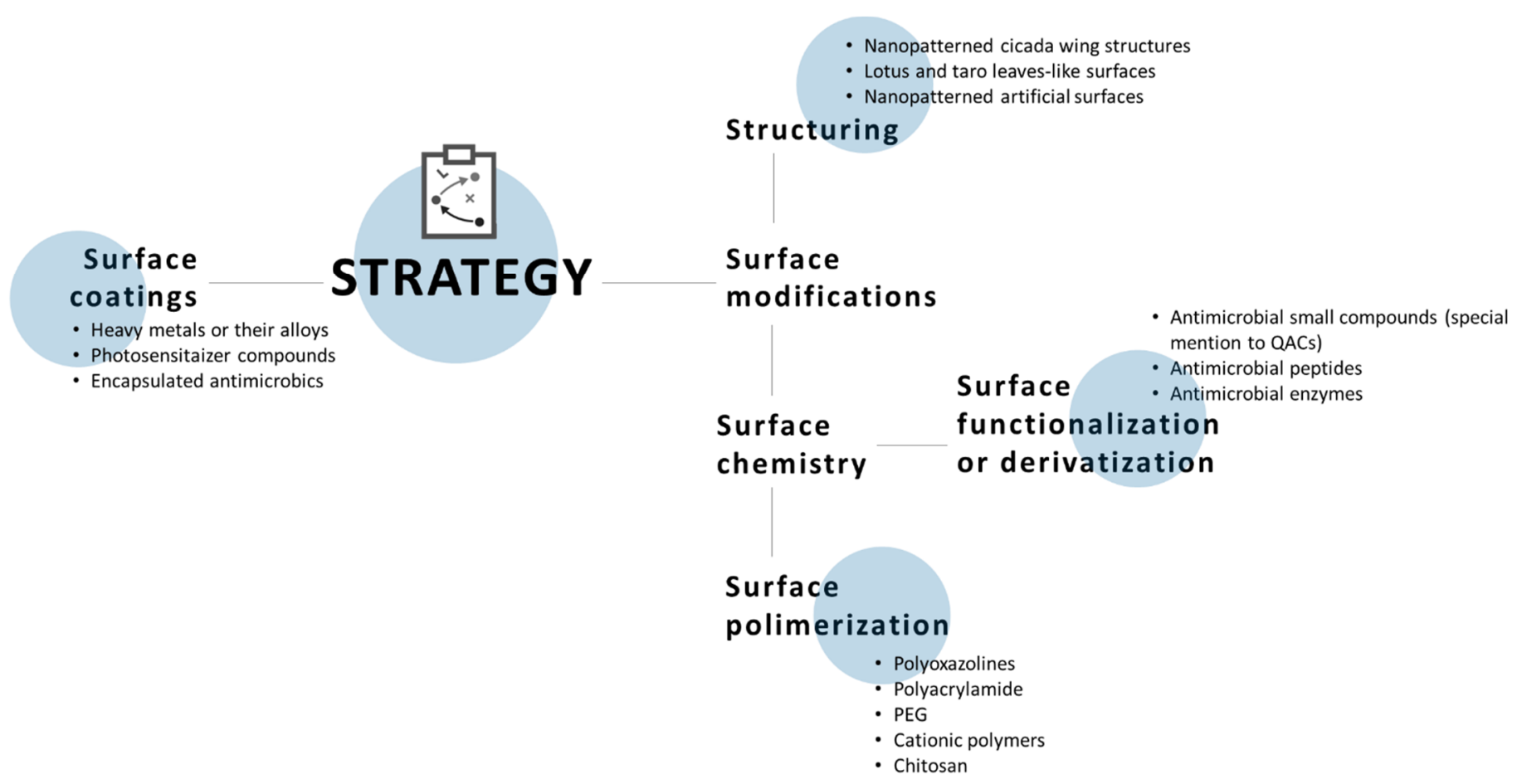

Figure 16. Different approaches in the design of antimicrobial surfaces.

\section{Current and Future Issues}

Antimicrobials are a precious resource that effectively keeps harmful microorganisms at bay. Unfortunately, nowadays, biocidal products are perceived as either direct and indirect threats. The direct one is due to the dissemination of resistant strains: the concept of bacterial resistance to biocides is not novel and the first evidence has been reported in the early 1950s [163]. This phenomenon has been associated with the increasing exposure to biocides; furthermore, several investigations describe a possible linkage between antimicrobial agents and the occurrence of antibiotic cross- and co-resistance [164,165]. The indirect threat regards the transfer of genes which confers resistance to a susceptible strain, enhancing its resistance level. Among the several routes for the transfer of genes, horizontal gene transfer (HGT) $[166,167]$ enables the exchange of transposons, integrons, and plasmids where antibiotic resistance genes are generally located. Lu et al. [168] demonstrate that high environmental concentrations of triclosan promote HGT of multidrug resistance genes between bacteria providing resistant strains. Another example regards the extensive use of QAC that has been blamed for the spread of QAC-resistance bacteria, both Gram-positive and negative. Resistance's mechanisms to this class of compounds are underexplored, however, efflux pump and alteration of membrane composition are among the predominant ones $[169,170]$.

Another example of antimicrobial resistance can be found in the tolerance to oxidizing biocides, like chlorine, hydrogen peroxide, and peracetic acid, which has also been described [171]. Resistance to these agents can result from the overproduction of enzymes which increases the defense towards radical-mediated damage or protects from biofilm's alterations.

The selective pressure towards disinfectants may occur also when biocides are discharged into the environment, themselves, or their residues [172,173]. McBain et al. [174] investigate the effects of triclosan use on the domestic-drain biofilm ecosystems. They found out that the biocide did not significantly lower the total counts but altered the bacterial composition, due to innate resistance or insusceptibility of some species able to degrade triclosan. Hospital wastewaters have been investigated as well $[175,176]$ as they are characterized by a high concentration of antibiotics and disinfectants. 
However, the lack of data on the majority of antimicrobial compounds prevents one from clearly identifying the risk arising from the increase and indiscriminate use of these biocides.

In conclusion, the consciousness that the perfect antimicrobial agent may not yet exist the right choice and the appropriate use of the current chemicals are necessary to avoid both resistance and environmental issues. For this purpose, a deep knowledge of the antimicrobial agent together with the type of surface would result in an effective and suitable disinfection level.

Author Contributions: Conceptualization, A.A. and L.F.; methodology, L.F.; data curation, A.A., S.M., and L.F.; writing — original draft preparation, A.A., S.M., and L.F.; writing-review and editing, A.A., S.M., and L.F.; visualization, A.A.; supervision, L.F.; project administration, L.F. A.A. and S.M. equally contributed to the overall preparation. All authors have read and agreed to the published version of the manuscript.

Funding: This research received no external funding.

Institutional Review Board Statement: Not Applicable.

Informed Consent Statement: Not Applicable.

Data Availability Statement: Not Applicable.

Conflicts of Interest: The authors declare no conflict of interest.

\section{References}

1. Kramer, A.; Schwebke, I.; Kampf, G. How long do nosocomial pathogens persist on inanimate surfaces? A systematic review. BMC Infect. Dis. 2006, 6, 130. [CrossRef]

2. Hayden, M.K.; Blom, D.W.; Lyle, E.A.; Moore, C.G.; Weinstein, R.A. Risk of Hand or Glove Contamination After Contact With Patients Colonized With Vancomycin-Resistant Enterococcus or the Colonized Patients' Environment. Infect. Control Hosp. Epidemiol. 2008, 29, 149-154. [CrossRef] [PubMed]

3. Duckro, A.N.; Blom, D.W.; Lyle, E.A.; Weinstein, R.A.; Hayden, M.K. Transfer of vancomycin-resistant enterococci via health care worker hands. Arch. Intern. Med. 2005, 165, 302-307. [CrossRef]

4. Guerrero, D.M.; Nerandzic, M.M.; Jury, L.A.; Jinno, S.; Chang, S.; Donskey, C.J. Acquisition of spores on gloved hands after contact with the skin of patients with Clostridium difficile infection and with environmental surfaces in their rooms. Am. J. Infect. Control 2012, 40, 556-558. [CrossRef]

5. Stiefel, U.; Cadnum, J.L.; Eckstein, B.C.; Guerrero, D.M.; Tima, M.A.; Donskey, C.J. Contamination of Hands with MethicillinResistant Staphylococcus aureus after Contact with Environmental Surfaces and after Contact with the Skin of Colonized Patients. Infect. Control Hosp. Epidemiol. 2011, 32, 185-187. [CrossRef] [PubMed]

6. Janeway, C.A., Jr.; Travers, P.; Walport, M. Infectious agents and how they cause disease. In Immunobiology: The Immune System in Health and Disease, 5th ed.; Garland Science: New York, NY, USA, 2001; p. 27114.

7. Julian, T.R.; Tamayo, F.J.; Leckie, J.O.; Boehm, A.B. Comparison of surface sampling methods for virus recovery from fomites. Appl. Environ. Microbiol. 2011, 77, 6918-6925. [CrossRef] [PubMed]

8. Silhavy, T.J.; Kahne, D.; Walker, S. The bacterial cell envelope. Cold Spring Harb. Perspect. Biol. 2010, 2. [CrossRef]

9. Auer, G.K.; Weibel, D.B. Bacterial Cell Mechanics. Biochemistry 2017, 56, 3710-3724. [CrossRef]

10. Esko, J.D.; Doering, T.L.; Raetz, C.R. Eubacteria and Archaea. In Essentials of Glycobiology, 2nd ed.; Gerald, W.H., Marilynn, E.E., Eds.; Cold Spring Harbor Laboratory Press: Long Island, NY, USA, 2009; Chapter 20.

11. Brown, S.; Santa Maria, J.P.; Walker, S. Wall teichoic acids of gram-positive bacteria. Annu. Rev. Microbiol. 2013, 67, 313-336. [CrossRef] [PubMed]

12. Dufrêne, Y.F.; Persat, A. Mechanomicrobiology: How bacteria sense and respond to forces. Nat. Rev. Microbiol. 2020, 18, 227-240. [CrossRef]

13. Nicholson, W.L.; Fajardo-Cavazos, P.; Rebeil, R.; Slieman, T.A.; Riesenman, P.J.; Law, J.F.; Xue, Y. Bacterial endospores and their significance in stress resistance. Antonie Van Leeuwenhoek 2002, 81, 27-32. [CrossRef] [PubMed]

14. Mallozzi, M.; Viswanathan, V.K.; Vedantam, G. Spore-forming Bacilli and Clostridia in human disease. Future Microbiol. 2010, 5, 1109-1123. [CrossRef] [PubMed]

15. Chen, Y.; Norde, W.; van der Mei, H.C.; Busscher, H.J. Bacterial cell surface deformation under external loading. mBio $2012,3$. [CrossRef] [PubMed]

16. Donlan, R.M. Biofilms: Microbial life on surfaces. Emerg. Infect. Dis. 2002, 8, 881-890. [CrossRef]

17. Sharma, D.; Misba, L.; Khan, A.U. Antibiotics versus biofilm: An emerging battleground in microbial communities. Antimicrob. Resist. Infect. Control 2019, 8, 1-10. [CrossRef]

18. Bjarnsholt, T. The role of bacterial biofilms in chronic infections. APMIS Suppl. 2013, 121, 1-58. [CrossRef] 
19. Høiby, N. A short history of microbial biofilms and biofilm infections. APMIS 2017, 125, 272-275. [CrossRef]

20. Gristina, A.G.; Costerton, J.W. Bacterial adherence and the glycocalyx and their role in musculoskeletal infection. Orthop. Clin. N. Am. 1984, 15, 517-535. [CrossRef]

21. Gelderblom, H.R. Structure and Classification of Viruses. In Medical Microbiology, 4th ed.; University of Texas Medical Branch at Galveston: Galveston, TX, USA, 1996; Chapter 41.

22. Summers, W.C. Virus Infection. In Encyclopedia of Microbiology; Elsevier Inc.: Amsterdam, The Netherlands, 2009; pp. 546-552.

23. Lucas, W. Viral Capsids and Envelopes: Structure and Function. In Encyclopedia of Life Sciences; John Wiley \& Sons, Ltd.: Chichester, UK, 2010.

24. Louten, J. Virus Structure and Classification. In Essential Human Virology; Elsevier: Amsterdam, The Netherlands, 2016 ; pp. 19-29.

25. Ruiz-Herrera, J.; Ortiz-Castellanos, L. Cell wall glucans of fungi. A review. Cell Surf. 2019, 5, 100022. [CrossRef]

26. Taylor, T.N.; Osborn, J.M. The importance of fungi in shaping the paleoecosystem. Rev. Palaeobot. Palynol. 1996, 90, 249-262. [CrossRef]

27. Classification of Biological Agents_-Health and Safety Authority. Available online: https://www.hsa.ie/eng/publications_and_ forms/publications/biological_agents/biological_agents_code_of_practice_2020.html (accessed on 20 April 2021).

28. Hayden, M.K.; Bonten, M.J.M.; Blom, D.W.; Lyle, E.A.; van de Vijver, D.A.M.C.; Weinstein, R.A. Reduction in Acquisition of Vancomycin-Resistant Enterococcus after Enforcement of Routine Environmental Cleaning Measures. Clin. Infect. Dis. 2006, 42, 1552-1560. [CrossRef] [PubMed]

29. Dettenkofer, M.; Block, C. Hospital disinfection: Efficacy and safety issues. Curr. Opin. Infect. Dis. 2005, 18, 320-325. [CrossRef] [PubMed]

30. Stewart, P.S.; Costerton, J.W. Antibiotic resistance of bacteria in biofilms. Lancet 2001, 358, 135-138. [CrossRef]

31. Johnson, A.C.; Jin, X.; Nakada, N.; Sumpter, J.P. Learning from the past and considering the future of chemicals in the environment. Science 2020, 367, 384-387. [CrossRef]

32. World Health Organization. Laboratory Biosafety Manual, 3rd ed.; WHO: Geneva, Switzerland, 2004.

33. Albrich, J.M.; McCarthy, C.A.; Hurst, J.K. Biological reactivity of hypochlorous acid: Implications for microbicidal mechanisms of leukocyte myeloperoxidase. Proc. Natl. Acad. Sci. USA 1981, 78, 210-214. [CrossRef]

34. Brazis, A.R.; Leslie, J.E.; Kabler, P.W.; Woodward, R.L. The inactivation of spores of Bacillus globigii and Bacillus anthracis by free available chlorine. Appl. Microbiol. 1958, 6, 338-342. [CrossRef]

35. Hawkins, C.L.; Pattison, D.I.; Davies, M.J. Hypochlorite-induced oxidation of amino acids, peptides and proteins. Amino Acids 2003, 25, 259-274. [CrossRef]

36. Winter, J.; Ilbert, M.; Graf, P.C.F.; Özcelik, D.; Jakob, U. Bleach Activates a Redox-Regulated Chaperone by Oxidative Protein Unfolding. Cell 2008, 135, 691-701. [CrossRef]

37. Adam, L.C.; Suzuki, K.; Gordon, G.; Fábián, I. Hypochlorous Acid Decomposition in the pH 5-8 Region. Inorg. Chem. 1992, 31, 3534-3541. [CrossRef]

38. White, G.C. Handbook of Chlorination and Alternative Disinfectants; John Wiley \& Sons Ltd.: Hoboken, NJ, USA, 1999 ; Volume 77.

39. Heseltine, P. Disinfection, Sterilization, and Preservation, 5th ed. SS Block, ed.; Philadelphia: Lippincott Williams \& Wilkins, 2001; 1504 pages. Infect. Control Hosp. Epidemiol. 2002, 23, 109. [CrossRef]

40. Fukuzaki, S. Mechanisms of Actions of Sodium Hypochlorite in Cleaning and Disinfection Processes. Biocontrol Sci. 2006, 11, 147-157. [CrossRef]

41. Kuroiwa, K.; Nakayama, H.; Kuwahara, T.; Tamagawa, K.; Hattori, K.; Murakami, K.; Korai, H.; Ohnishi, Y. Augmenting effect of acetic acid for acidification on bactericidal activity of hypochlorite solution. Lett. Appl. Microbiol. 2003, 36, 46-49. [CrossRef] [PubMed]

42. European Chemicals Agency. Evaluation of active substances Assessment Report Cholecalciferol PT 14 (Rodenticides). In Regulation (EU) No 528/2012 Concerning the Making Available on the Market and Use of Biocidal Products; ECHA: Helsinki, Finland, 2018.

43. Iqbal, Q.; Lubeck-Schricker, M.; Wells, E.; Wolfe, M.K.; Lantagne, D. Shelf-Life of Chlorine Solutions Recommended in Ebola Virus Disease Response. PLoS ONE 2016, 11, e0156136. [CrossRef]

44. Coates, D. A comparison of sodium hypochlorite and sodium dichloroisocyanurate products. J. Hosp. Infect. 1985, 6, 31-40. [CrossRef]

45. Bloomfield, S.F.; Uso, E.E. The antibacterial properties of sodium hypochlorite and sodium dichloroisocyanurate as hospital disinfectants. J. Hosp. Infect. 1985, 6, 20-30. [CrossRef]

46. Coates, D. Comparison of sodium hypochlorite and sodium dichloroisocyanurate disinfectants: Neutralization by serum. J. Hosp. Infect. 1988, 11, 60-67. [CrossRef]

47. Bloomfield, S.F.; Arthur, M.; Begun, K.; Patel, H. Comparative testing of disinfectants using proposed European surface test methods. Lett. Appl. Microbiol. 1993, 17, 119-125. [CrossRef]

48. Gallandat, K.; Wolfe, M.K.; Lantagne, D. Surface Cleaning and Disinfection: Efficacy Assessment of Four Chlorine Types Using Escherichia coli and the Ebola Surrogate Phi6. Environ. Sci. Technol. 2017, 51, 4624-4631. [CrossRef]

49. Aarnisalo, K.; Salo, S.; Miettinen, H.; Suihko, M.L.; Wirtanen, G.; Autio, T.; Lundén, J.; Korkeala, H.; Sjöberg, A.M. Bactericidal efficiencies of commercial disinfectants against listeria monocytogenes on surfaces. J. Food Saf. 2000, 20, 237-250. [CrossRef]

50. Mbithi, J.N.; Springthorpe, V.S.; Sattar, S.A. Chemical Disinfection of Hepatitis A Virus on Environmental Surfaces. Appl. Environ. Microbiol. 1990, 56, 3601-3604. [CrossRef] 
51. Bichsel, Y. Behavior of Iodine Species in Oxidative Processing during Drinking Water Treatment. Ph.D. Thesis, Swiss Federal Institute of Technology Zurich, Zürich, Switzerland, 2000.

52. Al-Adham, I.; Haddadin, R.; Collier, P. Types of Microbicidal and Microbistatic Agents. In Russell, Hugo E Ayliffe's: Principles and Practice of Disinfection, Preservation and Sterilization; John Wiley \& Sons: Hoboken, NJ, USA, 2012; pp. 5-70.

53. Block, C.; Robenshtok, E.; Simhon, A.; Shapiro, M. Evaluation of chlorhexidine and povidone iodine activity against methicillinresistant Staphylococcus aureus and vancomycin-resistant Enterococcus faecalis using a surface test. J. Hosp. Infect. 2000, 46, 147-152. [CrossRef] [PubMed]

54. Morton, H.E. The relationship of concentration and germicidal efficiency of ethyl alcohol. Ann. N. Y. Acad. Sci. 1950, 53, 191-196. [CrossRef] [PubMed]

55. Coulthard, C.E.; Sykes, G. The germicidal effect of alcohol with special reference to its action on bacterial spores. Pharm. J. 1936, $137,79-81$.

56. Rutala, W.A.; Weber, D.J. Guideline for Disinfection and Sterilization in Healthcare Facilities; CDC: Atlanta, GA, USA, 2008.

57. Doerrbecker, J.; Friesland, M.; Ciesek, S.; Erichsen, T.J.; Mateu-Gelabert, P.; Steinmann, J.; Pietschmann, T.; Steinmann, E. Inactivation and survival of hepatitis C virus on inanimate surfaces. J. Infect. Dis. 2011, 204, 1830-1838. [CrossRef] [PubMed]

58. Chemical Disinfectants. Disinfection \& Sterilization Guidelines. Guidelines Library. Infection Control. CDC. Available online: https:/ / www.cdc.gov/infectioncontrol/guidelines/disinfection/disinfection-methods / chemical.html\# (accessed on 8 January 2021).

59. Gilbert, P.; McBain, A.J. Potential impact of increased use of biocides in consumer products on prevalence of antibiotic resistance. Clin. Microbiol. Rev. 2003, 16, 189-208. [CrossRef]

60. Fraise, A.P. Choosing disinfectants. J. Hosp. Infect. 1999, 43, 255-264. [CrossRef]

61. Harrington, C.; Walker, H. The Germicidal Action of Alcohol. Boston Med. Surg. J. 1903, 148, 548-552. [CrossRef]

62. Salvage, R.; Hull, C.M.; Kelly, D.E.; Kelly, S.L. Use of 70\% alcohol for the routine removal of microbial hard surface bioburden in life science cleanrooms. Future Microbiol. 2014, 9, 1123-1130. [CrossRef]

63. Rutala, W.A.; Weber, D.J. Monitoring and improving the effectiveness of surface cleaning and disinfection. Am. J. Infect. Control 2016, 44, e69-e76. [CrossRef] [PubMed]

64. Rotter, M.L. Arguments for alcoholic hand disinfection. J. Hosp. Infect. 2001, 48, S4-S8. [CrossRef]

65. Withell, E.R. The evaluation of bactericides. J. Hyg. (Lond.) 1942, 42, 339-353. [CrossRef] [PubMed]

66. O'Neil, M. The Merck Index: An Encyclopedia of Chemicals, Drugs, and Biologicals, 13th ed.; Merck \& Co., Inc.: Whitehouse Station, NJ, USA, 2001.

67. Lambert, P.A.; Hammond, S.M. Potassium fluxes, first indications of membrane damage in micro-organisms. Biochem. Biophys. Res. Commun. 1973, 54, 796-799. [CrossRef]

68. Judis, J. Mechanism of action of phenolic disinfectants IV. Effects on induction of and accessibility of substrate to $\beta$-galactosidase in Escherichia coli. J. Pharm. Sci. 1965, 54, 417-420. [CrossRef]

69. Suter, C.M. Relationships between the structure and the bactericidal properties of phenols. Chem. Rev. 1941, 28, 269-299. [CrossRef]

70. Terleckyj, B.; Axler, D.A. Quantitative neutralization assay of fungicidal activity of disinfectants. Antimicrob. Agents Chemother. 1987, 31, 794-798. [CrossRef] [PubMed]

71. Martin, L.S.; McDougal, J.S.; Loskoski, S.L. Disinfection and Inactivation of the Human T Lymphotropic Virus Type III/Lymphadenopathy-Associated Virus. J. Infect. Dis. 1985, 152, 400-403. [CrossRef]

72. Sattar, S.A.; Springthorpe, V.S. Survival and disinfectant inactivation of the human immunodeficiency virus: A critical review. Rev. Infect. Dis. 1991, 13, 430-447. [CrossRef]

73. Sagripanti, J.L.; Eklund, C.A.; Trost, P.A.; Jinneman, K.C.; Abeyta, C.; Kaysner, C.A.; Hill, W.E. Comparative sensitivity of 13 species of pathogenic bacteria to seven chemical germicides. Am. J. Infect. Control 1997, 25, 335-339. [CrossRef]

74. Narang, H.K.; Codd, A.A. Action of commonly used disinfectants against enteroviruses. J. Hosp. Infect. 1983, 4, 209-212. [CrossRef]

75. Rutala, W.A.; Weber, D.J. Disinfection and Sterilization in Health Care Facilities: An Overview and Current Issues. Infect. Dis. Clin. 2016, 30, 609-637. [CrossRef]

76. Doan, H.M.; Keith, L.; Shennan, A.T. Phenol and Neonatal Jaundice. Pediatrics 1979, 64, 324-325. [PubMed]

77. Calafat, A.M.; Weuve, J.; Ye, X.; Jia, L.T.; Hu, H.; Ringer, S.; Huttner, K.; Hauser, R. Exposure to bisphenol A and other phenols in neonatal intensive care unit premature infants. Environ. Health Perspect. 2009, 117, 639-644. [CrossRef] [PubMed]

78. Zhang, C.; Cui, F.; Zeng, G.; Jiang, M.; Yang, Z.; Yu, Z.; Zhu, M.; Shen, L. Quaternary ammonium compounds (QACs): A review on occurrence, fate and toxicity in the environment. Sci. Total Environ. 2015, 518, 352-362. [CrossRef] [PubMed]

79. Ying, G.G. Fate, behavior and effects of surfactants and their degradation products in the environment. Environ. Int. 2006, 32, 417-431. [CrossRef]

80. Tezel, U.; Pavlostathis, S.G. Role of Quaternary Ammonium Compounds on Antimicrobial Resistance in the Environment. In Antimicrobial Resistance in the Environment; John Wiley \& Sons, Inc.: Hoboken, NJ, USA, 2011; pp. 349-387.

81. Fumagalli, L.; Regazzoni, L.G.; Straniero, V.; Valoti, E.; Aldini, G.; Vistoli, G.; Carini, M.; Picozzi, C. Stressed degradation studies of domiphen bromide by LC-ESI-MS/MS identify a novel promising antimicrobial agent. J. Pharm. Biomed. Anal. 2018, 159, 224-228. [CrossRef] 
82. Wessels, S.; Ingmer, H. Modes of action of three disinfectant active substances: A review. Regul. Toxicol. Pharmacol. 2013, 67, 456-467. [CrossRef]

83. Zinchenko, A.A.; Sergeyev, V.G.; Yamabe, K.; Murata, S.; Yoshikawa, K. DNA compaction by divalent cations: Structural specificity revealed by the potentiality of designed quaternary diammonium salts. ChemBioChem 2004, 5, 360-368. [CrossRef]

84. Gerba, C.P. Quaternary ammonium biocides: Efficacy in application. Appl. Environ. Microbiol. 2015, 81, 464-469. [CrossRef]

85. Rutala, W.A.; White, M.S.; Gergen, M.F.; Weber, D.J. Bacterial Contamination of Keyboards: Efficacy and Functional Impact of Disinfectants. Infect. Control Hosp. Epidemiol. 2006, 27, 372-377. [CrossRef]

86. Brown, E.; Dhanireddy, K.; Teska, P.; Eifert, J.; Williams, R.C.; Boyer, R. Influence of drying time on prewetted disinfectant towelettes to disinfect glass surfaces. Am. J. Infect. Control 2020, 48, 846-848. [CrossRef]

87. Cousins, C.M.; Clegg, L.F.L. The effect of water hardness and temperature on water sterilization by mixtures of detergents and quaternary ammonium compounds. J. Appl. Bacteriol. 1956, 19, 250-255. [CrossRef]

88. Song, X.; Vossebein, L.; Zille, A. Efficacy of disinfectant-impregnated wipes used for surface disinfection in hospitals: A review. Antimicrob. Resist. Infect. Control 2019, 8, 1-14. [CrossRef] [PubMed]

89. Purohit, A.; Kopferschmitt-Kubler, M.C.; Moreau, C.; Popin, E.; Blaumeiser, M.; Pauli, G. Quaternary ammonium compounds and occupational asthma. Int. Arch. Occup. Environ. Health 2000, 73, 423-427. [CrossRef]

90. Schyllert, C.; Rönmark, E.; Andersson, M.; Hedlund, U.; Lundbäck, B.; Hedman, L.; Lindberg, A. Occupational exposure to chemicals drives the increased risk of asthma and rhinitis observed for exposure to vapours, gas, dust and fumes: A cross-sectional population-based study. Occup. Environ. Med. 2016, 73, 663-669. [CrossRef] [PubMed]

91. Zock, J.P.; Plana, E.; Jarvis, D.; Antó, J.M.; Kromhout, H.; Kennedy, S.M.; Künzli, N.; Villani, S.; Olivieri, M.; Torén, K.; et al. The use of household cleaning sprays and adult asthma: An international longitudinal study. Am. J. Respir. Crit. Care Med. 2007, 176, 735-741. [CrossRef] [PubMed]

92. Kampf, G.; Degenhardt, S.; Lackner, S.; Jesse, K.; von Baum, H.; Ostermeyer, C. Poorly processed reusable surface disinfection tissue dispensers may be a source of infection. BMC Infect. Dis. 2014, 14, 1-8. [CrossRef] [PubMed]

93. Pereira, B.M.P.; Tagkopoulos, I. Benzalkonium chlorides: Uses, regulatory status, and microbial resistance. Appl. Environ. Microbiol. 2019, 85. [CrossRef]

94. Baldry, M.G.C. The bactericidal, fungicidal and sporicidal properties of hydrogen peroxide and peracetic acid. J. Appl. Bacteriol. 1983, 54, 417-423. [CrossRef] [PubMed]

95. Absalan, A.; Ehrampoush, M.; Davoudi, M.; Vakili, T.; Ebrahimi, A. Antibacterial effects of hydrogen peroxide and silver composition on selected pathogenic enterobacteriaceae. Int. J. Environ. Health Eng. 2012, 1, 23. [CrossRef]

96. Steinberg, D.; Heling, I.; Daniel, I.; Ginsburg, I. Antibacterial synergistic effect of chlorhexidine and hydrogen peroxide against Streptococcus sobrinus, Streptococcus faecalis and Staphylococcus aureus. J. Oral Rehabil. 1999, 26, 151-156. [CrossRef]

97. Martin, N.L.; Bass, P.; Liss, S.N. Antibacterial properties and mechanism of activity of a novel silver-stabilized hydrogen peroxide. PLoS ONE 2015, 10, e0131345. [CrossRef]

98. McDonnell, G. The Use of Hydrogen Peroxide for Disinfection and Sterilization Applications. In Patai's Chemistry of Functional Groups; John Wiley \& Sons, Ltd.: Hoboken, NJ, USA, 2014; pp. 1-34.

99. Fraise, A.P.; Lambert, P.A.; Maillard, J.Y. Russell, Hugo and Ayliffe's Principles and Practice of Disinfection, Preservation and Sterilization, 4th ed.; John Wiley \& Sons: Hoboken, NJ, USA, 2008.

100. Totaro, M.; Casini, B.; Profeti, S.; Tuvo, B.; Privitera, G.; Baggiani, A. Role of hydrogen peroxide vapor (HPV) for the disinfection of hospital surfaces contaminated by multiresistant bacteria. Pathogens 2020, 9, 408. [CrossRef]

101. Weber, D.J.; Kanamori, H.; Rutala, W.A. "No touch" technologies for environmental decontamination: Focus on ultraviolet devices and hydrogen peroxide systems. Curr. Opin. Infect. Dis. 2016, 29, 424-431. [CrossRef]

102. Tuladhar, E.; Terpstra, P.; Koopmans, M.; Duizer, E. Virucidal efficacy of hydrogen peroxide vapour disinfection. J. Hosp. Infect. 2012, 80, 110-115. [CrossRef] [PubMed]

103. Orlando, P.; Cristina, M.L.; Dallera, M.; Ottria, G.; Vitale, A.; Badolati, G. Surface disinfection: Evaluation of the efficacy of a nebulization system spraying hydrogen peroxide. J. Prev. Med. Hyg. 2008, 49, 116-119. [CrossRef]

104. Domínguez Henao, L.; Turolla, A.; Antonelli, M. Disinfection by-products formation and ecotoxicological effects of effluents treated with peracetic acid: A review. Chemosphere 2018, 213, 25-40. [CrossRef]

105. Cutts, T.; Kasloff, S.; Safronetz, D.; Krishnan, J. Decontamination of common healthcare facility surfaces contaminated with SARS-CoV-2 using peracetic acid dry fogging. J. Hosp. Infect. 2021, 109, 82-87. [CrossRef] [PubMed]

106. Mcdonnell, G.; Russell, A.D. Antiseptics and disinfectants: Activity, action, and resistance. Clin. Microbiol. Rev. 1999, 12, 147-179. [CrossRef]

107. Rutala, W.A.; Weber, D.J. New disinfection and sterilization methods. Emerg. Infect. Dis. 2001, 7, 348-353. [CrossRef] [PubMed]

108. Gehr, R.; Chen, D.; Moreau, M. Performic acid (PFA): Tests on an advanced primary effluent show promising disinfection performance. Water Sci. Technol. 2009, 59, 89-96. [CrossRef]

109. Rickloff, J.R. An evaluation of the sporicidal activity of ozone. Appl. Environ. Microbiol. 1987, 53, 683-686. [CrossRef] [PubMed]

110. Martinelli, M.; Giovannangeli, F.; Rotunno, S.; Trombetta, C.M.; Montomoli, E. Water and air ozone treatment as an alternative sanitizing technology. J. Prev. Med. Hyg. 2017, 58, E48-E52. [CrossRef]

111. Breidablik, H.J.; Lysebo, D.E.; Johannessen, L.; Skare, Å.; Andersen, J.R.; Kleiven, O.T. Ozonized water as an alternative to alcohol-based hand disinfection. J. Hosp. Infect. 2019, 102, 419-424. [CrossRef] [PubMed] 
112. Megahed, A.; Aldridge, B.; Lowe, J. The microbial killing capacity of aqueous and gaseous ozone on different surfaces contaminated with dairy cattle manure. PLoS ONE 2018, 13, e0196555. [CrossRef]

113. Burleson, G.R.; Murray, T.M.; Pollard, M. Inactivation of Viruses and Bacteria by Ozone, With and Without Sonication. Appl. Microbiol. 1975, 29, 340-344. [CrossRef]

114. Albert, S.; Amarilla, A.A.; Trollope, B.; Sng, J.D.J.; Setoh, Y.X.; Deering, N.; Modhiran, N.; Weng, S.H.; Melo, M.C.; Hutley, N.; et al. Assessing the potential of unmanned aerial vehicle spraying of aqueous ozone as an outdoor disinfectant for SARS-CoV-2. Environ. Res. 2021, 196, 110944. [CrossRef]

115. Megahed, A.; Aldridge, B.; Lowe, J. Comparative study on the efficacy of sodium hypochlorite, aqueous ozone, and peracetic acid in the elimination of Salmonella from cattle manure contaminated various surfaces supported by Bayesian analysis. PLoS ONE 2019, 14, e0217428. [CrossRef] [PubMed]

116. Grignani, E.; Mansi, A.; Cabella, R.; Castellano, P.; Tirabasso, A.; Sisto, R.; Spagnoli, M.; Fabrizi, G.; Frigerio, F.; Tranfo, G. Safe and Effective Use of Ozone as Air and Surface Disinfectant in the Conjuncture of Covid-19. Gases 2020, 1, 19-32. [CrossRef]

117. Selma, M.V.; Allende, A.; López-Gálvez, F.; Conesa, M.A.; Gil, M.I. Disinfection potential of ozone, ultraviolet-C and their combination in wash water for the fresh-cut vegetable industry. Food Microbiol. 2008, 25, 809-814. [CrossRef] [PubMed]

118. Zoutman, D.; Shannon, M.; Mandel, A. Effectiveness of a novel ozone-based system for the rapid high-level disinfection of health care spaces and surfaces. Am. J. Infect. Control 2011, 39, 873-879. [CrossRef]

119. Fang, J.; Liu, H.; Shang, C.; Zeng, M.; Ni, M.; Liu, W.E. coli and bacteriophage MS2 disinfection by UV, ozone and the combined UV and ozone processes. Front. Environ. Sci. Eng. 2014, 8, 547-552. [CrossRef]

120. Fan, L.; Song, J.; Hildebrand, P.D.; Forney, C.F. Interaction of ozone and negative air ions to control micro-organisms. J. Appl. Microbiol. 2002, 93, 144-148. [CrossRef] [PubMed]

121. Gray, N.F. Ultraviolet Disinfection. In Microbiology of Waterborne Diseases, 2nd ed.; Academic Press: Cambridge, MA, USA, 2014; pp. 617-630.

122. Bolton, J.R.; Dussert, B.; Bukhari, Z.; Hargy, T.; Clancy, J.L. Inactivation of Cryptosporidium parvum by medium-pressure ultraviolet light in finished drinking water. In Proceedings of the AWWA 1998 Annual Conference, Dallas, TX, USA, 21-25 June 1998; Volume A, pp. 389-403.

123. Rutala, W.A.; Gergen, M.F.; Weber, D.J. Room Decontamination with UV Radiation. Infect. Control Hosp. Epidemiol. 2010, 31, 1025-1029. [CrossRef]

124. Lindblad, M.; Tano, E.; Lindahl, C.; Huss, F. Ultraviolet-C decontamination of a hospital room: Amount of UV light needed. Burns 2020, 46, 842-849. [CrossRef]

125. Oguma, K.; Katayama, H.; Ohgaki, S. Photoreactivation of Escherichia coli after low- or medium-pressure UV disinfection determined by an endonuclease sensitive site assay. Appl. Environ. Microbiol. 2002, 68, 6029-6035. [CrossRef] [PubMed]

126. Casini, B.; Tuvo, B.; Cristina, M.L.; Spagnolo, A.M.; Totaro, M.; Baggiani, A.; Privitera, G.P. Evaluation of an ultraviolet C (UVC) light-emitting device for disinfection of high touch surfaces in hospital critical areas. Int. J. Environ. Res. Public Health 2019, 16, 3572. [CrossRef]

127. Kumar, A.; Sagdeo, A.; Sagdeo, P.R. Possibility of using ultraviolet radiation for disinfecting the novel COVID-19. Photodiagn. Photodyn. Ther. 2021, 34, 102234. [CrossRef]

128. Kitagawa, H.; Nomura, T.; Nazmul, T.; Omori, K.; Shigemoto, N.; Sakaguchi, T.; Ohge, H. Effectiveness of 222-nm ultraviolet light on disinfecting SARS-CoV-2 surface contamination. Am. J. Infect. Control 2021, 49, 299-301. [CrossRef]

129. Jelden, K.C.; Gibbs, S.G.; Smith, P.W.; Hewlett, A.L.; Iwen, P.C.; Schmid, K.K.; Lowe, J.J. Comparison of hospital room surface disinfection using a novel ultraviolet germicidal irradiation (UVGI) generator. J. Occup. Environ. Hyg. 2016, 13, 690-698. [CrossRef]

130. Umezawa, K.; Asai, S.; Inokuchi, S.; Miyachi, H. A comparative study of the bactericidal activity and daily disinfection housekeeping surfaces by a new portable pulsed UV radiation device. Curr. Microbiol. 2012, 64, 581-587. [CrossRef]

131. Kovach, C.R.; Taneli, Y.; Neiman, T.; Dyer, E.M.; Arzaga, A.J.A.; Kelber, S.T. Evaluation of an ultraviolet room disinfection protocol to decrease nursing home microbial burden, infection and hospitalization rates. BMC Infect. Dis. 2017, 17, 1-8. [CrossRef] [PubMed]

132. Rutala, W.A.; Gergen, M.F.; Tande, B.M.; Weber, D.J. Rapid Hospital Room Decontamination Using Ultraviolet (UV) Light with a Nanostructured UV-Reflective Wall Coating. Infect. Control Hosp. Epidemiol. 2013, 34, 527-529. [CrossRef] [PubMed]

133. Tiller, J.C. Antimicrobial surfaces. Adv. Polym. Sci. 2010, 240, 193-217.

134. Linklater, D.P.; Baulin, V.A.; Juodkazis, S.; Crawford, R.J.; Stoodley, P.; Ivanova, E.P. Mechano-bactericidal actions of nanostructured surfaces. Nat. Rev. Microbiol. 2021, 19, 8-22. [CrossRef]

135. Webb, H.K.; Hasan, J.; Truong, V.K.; Crawford, R.J.; Ivanova, E.P. Nature Inspired Structured Surfaces for Biomedical Applications. Curr. Med. Chem. 2011, 18, 3367-3375. [CrossRef] [PubMed]

136. Nguyen, S.H.T.; Webb, H.K.; Hasan, J.; Tobin, M.J.; Crawford, R.J.; Ivanova, E.P. Dual role of outer epicuticular lipids in determining the wettability of dragonfly wings. Colloids Surf. B Biointerfaces 2013, 106, 126-134. [CrossRef]

137. Ivanova, E.P.; Nguyen, S.H.; Webb, H.K.; Hasan, J.; Truong, V.K.; Lamb, R.N.; Duan, X.; Tobin, M.J.; Mahon, P.J.; Crawford, R.J. Molecular Organization of the Nanoscale Surface Structures of the Dragonfly Hemianax papuensis Wing Epicuticle. PLoS ONE 2013, 8, e67893. [CrossRef]

138. Jenkins, J.; Mantell, J.; Neal, C.; Gholinia, A.; Verkade, P.; Nobbs, A.H.; Su, B. Antibacterial effects of nanopillar surfaces are mediated by cell impedance, penetration and induction of oxidative stress. Nat. Commun. 2020, 11, 1-14. [CrossRef] 
139. Knetsch, M.L.W.; Koole, L.H. New strategies in the development of antimicrobial coatings: The example of increasing usage of silver and silver nanoparticles. Polymers 2011, 3, 340-366. [CrossRef]

140. Maillard, J.Y.; Hartemann, P. Silver as an antimicrobial: Facts and gaps in knowledge. Crit. Rev. Microbiol. 2013, 39, 373-383. [CrossRef]

141. Weaver, L.; Noyce, J.O.; Michels, H.T.; Keevil, C.W. Potential action of copper surfaces on meticillin-resistant Staphylococcus aureus. J. Appl. Microbiol. 2010, 109, 2200-2205. [CrossRef] [PubMed]

142. Noyce, J.O.; Michels, H.; Keevil, C.W. Potential use of copper surfaces to reduce survival of epidemic meticillin-resistant Staphylococcus aureus in the healthcare environment. J. Hosp. Infect. 2006, 63, 289-297. [CrossRef] [PubMed]

143. Ruparelia, J.P.; Chatterjee, A.K.; Duttagupta, S.P.; Mukherji, S. Strain specificity in antimicrobial activity of silver and copper nanoparticles. Acta Biomater. 2008, 4, 707-716. [CrossRef] [PubMed]

144. Jin, S.E.; Jin, H.E. Antimicrobial activity of zinc oxide nano/microparticles and their combinations against pathogenic microorganisms for biomedical applications: From physicochemical characteristics to pharmacological aspects. Nanomaterials 2021, 11, 263. [CrossRef] [PubMed]

145. Da Silva, B.L.; Abuçafy, M.P.; Manaia, E.B.; Junior, J.A.O.; Chiari-Andréo, B.G.; Pietro, R.C.L.R.; Chiavacci, L.A. Relationship between structure and antimicrobial activity of zinc oxide nanoparticles: An overview. Int. J. Nanomed. 2019, 14, 9395-9410. [CrossRef] [PubMed]

146. Grass, G.; Rensing, C.; Solioz, M. Metallic copper as an antimicrobial surface. Appl. Environ. Microbiol. 2011, 77, 1541-1547. [CrossRef]

147. Valeria Prado, J.; Roberto Vidal, A.; Claudia Durán, T. Aplicación de la capacidad bactericida del cobre en la práctica médica. Rev. Med. Chil. 2012, 140, 1325-1332. [CrossRef]

148. Vincent, M.; Hartemann, P.; Engels-Deutsch, M. Antimicrobial applications of copper. Int. J. Hyg. Environ. Health 2016, 219, 585-591. [CrossRef]

149. Villapún, V.M.; Dover, L.G.; Cross, A.; González, S. Antibacterial metallic touch surfaces. Materials 2016, 9, 736. [CrossRef]

150. Santos, M.R.E.; Mendonça, P.V.; Branco, R.; Sousa, R.; Dias, C.; Serra, A.C.; Fernandes, J.R.; Magalhães, F.D.; Morais, P.V.; Coelho, J.F.J. Light-Activated Antimicrobial Surfaces Using Industrial Varnish Formulations to Mitigate the Incidence of Nosocomial Infections. ACS Appl. Mater. Interfaces 2021, 13, 7567-7579. [CrossRef]

151. Wu, X.; Huang, Y.Y.; Kushida, Y.; Bhayana, B.; Hamblin, M.R. Broad-spectrum antimicrobial photocatalysis mediated by titanium dioxide and UVA is potentiated by addition of bromide ion via formation of hypobromite. Free Radic. Biol. Med. 2016, 95, 74-81. [CrossRef] [PubMed]

152. Visnapuu, M.; Rosenberg, M.; Truska, E.; Nõmmiste, E.; Šutka, A.; Kahru, A.; Rähn, M.; Vija, H.; Orupõld, K.; Kisand, V.; et al. UVA-induced antimicrobial activity of ZnO/Ag nanocomposite covered surfaces. Colloids Surf. B Biointerfaces 2018, 169, $222-232$. [CrossRef] [PubMed]

153. Eby, D.M.; Luckarift, H.R.; Johnson, G.R. Hybrid antimicrobial enzyme and silver nanoparticle coatings for medical Instruments. ACS Appl. Mater. Interfaces 2009, 1, 1553-1560. [CrossRef] [PubMed]

154. Rudra, J.S.; Dave, K.; Haynie, D.T. Antimicrobial polypeptide multilayer nanocoatings. J. Biomater. Sci. Polym. Ed. 2006, 17, 1301-1315. [CrossRef]

155. Waschinski, C.J.; Herdes, V.; Schueler, F.; Tiller, J.C. Influence of satellite groups on telechelic antimicrobial functions of polyoxazolines. Macromol. Biosci. 2005, 5, 149-156. [CrossRef]

156. Fundeanu, I.; van der Mei, H.C.; Schouten, A.J.; Busscher, H.J. Polyacrylamide brush coatings preventing microbial adhesion to silicone rubber. Colloids Surf. B 2008, 64, 297-301. [CrossRef]

157. Chapman, R.G.; Ostuni, E.; Liang, M.N.; Meluleni, G.; Kim, E.; Yan, L.; Pier, G.; Warren, H.S.; Whitesides, G.M. Polymeric thin films that resist the adsorption of proteins and the adhesion of bacteria. Langmuir 2001, 17, 1225-1233. [CrossRef]

158. D'Almeida, M.; Attik, N.; Amalric, J.; Brunon, C.; Renaud, F.; Abouelleil, H.; Toury, B.; Grosgogeat, B. Chitosan coating as an antibacterial surface for biomedical applications. PLOS ONE 2017, 12, e0189537. [CrossRef]

159. Alves, D.; Olívia Pereira, M. Mini-review: Antimicrobial peptides and enzymes as promising candidates to functionalize biomaterial surfaces. Biofouling 2014, 30, 483-499. [CrossRef]

160. Zubris, D.; Minbiole, K.; Wuest, W. Polymeric Quaternary Ammonium Compounds: Versatile Antimicrobial Materials. Curr. Top. Med. Chem. 2016, 17, 305-318. [CrossRef]

161. Grigoras, A.G. Natural and synthetic polymeric antimicrobials with quaternary ammonium moieties: A review. Environ. Chem. Lett. 2021, 1, 3.

162. Kenawy, E.R.; Worley, S.D.; Broughton, R. The chemistry and applications of antimicrobial polymers: A state-of-the-art review. Biomacromolecules 2007, 8, 1359-1384. [CrossRef] [PubMed]

163. Chapman, J.S. Biocide resistance mechanisms. Int. Biodeterior. Biodegrad. 2003, 51, 133-138. [CrossRef]

164. Amsalu, A.; Sapula, S.A.; Lopes, M.D.B.; Hart, B.J.; Nguyen, A.H.; Drigo, B.; Turnidge, J.; Leong, L.E.; Venter, H. Efflux pumpdriven antibiotic and biocide cross-resistance in pseudomonas Aeruginosa isolated from different ecological Niches: A case study in the development of multidrug resistance in environmental hotspots. Microorganisms 2020, 8, 1647. [CrossRef] [PubMed]

165. Paul, D.; Chakraborty, R.; Mandal, S.M. Biocides and health-care agents are more than just antibiotics: Inducing cross to co-resistance in microbes. Ecotoxicol. Environ. Saf. 2019, 174, 601-610. [CrossRef] [PubMed] 
166. Allen, H.K.; Donato, J.; Wang, H.H.; Cloud-Hansen, K.A.; Davies, J.; Handelsman, J. Call of the wild: Antibiotic resistance genes in natural environments. Nat. Rev. Microbiol. 2010, 8, 251-259. [CrossRef]

167. Blair, J.M.A.; Webber, M.A.; Baylay, A.J.; Ogbolu, D.O.; Piddock, L.J.V. Molecular mechanisms of antibiotic resistance. Nat. Rev. Microbiol. 2015, 13, 42-51. [CrossRef]

168. Lu, J.; Wang, Y.; Li, J.; Mao, L.; Nguyen, S.H.; Duarte, T.; Coin, L.; Bond, P.; Yuan, Z.; Guo, J. Triclosan at environmentally relevant concentrations promotes horizontal transfer of multidrug resistance genes within and across bacterial genera. Environ. Int. 2018, 121, 1217-1226. [CrossRef]

169. Jennings, M.C.; Forman, M.E.; Duggan, S.M.; Minbiole, K.P.C.; Wuest, W.M. Efflux Pumps Might Not Be the Major Drivers of QAC Resistance in Methicillin-Resistant Staphylococcus aureus. ChemBioChem 2017, 18, 1573-1577. [CrossRef]

170. Morrison, K.R.; Allen, R.A.; Minbiole, K.P.C.; Wuest, W.M. More QACs, more questions: Recent advances in structure activity relationships and hurdles in understanding resistance mechanisms. Tetrahedron Lett. 2019, 60, 150935. [CrossRef]

171. Dukan, S.; Touati, D. Hypochlorous acid stress in Escherichia coli: Resistance, DNA damage, and comparison with hydrogen peroxide stress. J. Bacteriol. 1996, 178, 6145-6150. [CrossRef] [PubMed]

172. Ribeiro, M.; Simões, L.C.; Simões, M. Biocides. In Encyclopedia of Microbiology; Elsevier: Amsterdam, The Netherlands, 2019; pp. $478-490$.

173. Siedlecka, A. Antibiotic and Disinfectant Resistance in Tap Water Strains-Insight into the Resistance of Environmental Bacteria. Pol. J. Microbiol. 2021, 70, 57-67. [CrossRef] [PubMed]

174. McBain, A.J.; Bartolo, R.G.; Catrenich, C.E.; Charbonneau, D.; Ledder, R.G.; Price, B.B.; Gilbert, P. Exposure of sink drain microcosms to triclosan: Population dynamics and antimicrobial susceptibility. Appl. Environ. Microbiol. 2003, 69, 5433-5442. [CrossRef]

175. Kümmerer, K. Resistance in the environment. J. Antimicrob. Chemother. 2004, 54, 311-320. [CrossRef] [PubMed]

176. Baquero, F.; Martínez, J.-L.; Cantón, R. Antibiotics and antibiotic resistance in water environments. Curr. Opin. Biotechnol. 2008, 19, 260-265. [CrossRef] [PubMed] 